\title{
Morphological variation of Aplectana hylambatis (Nematoda: Cosmocercidae) from different anuran hosts and localities in Argentina
}

\author{
CYNTHYA E. GONZÁLEZ, VALERIA I. GÓMEZ and MONIKA I. HAMANN
}

Centro de Ecología Aplicada del Litoral/CECOAL, Consejo Nacional de Investigaciones Científicas y Técnicas/ CONICET-UNNE, Ruta Provincial Número 5, Km 2.5, W 3400 AMD Corrientes, Provincia de Corrientes, Argentina

Manuscript received on December 22, 2017; accepted for publication on October 17, 2018

\begin{abstract}
How to cite: GONZÁLEZ CE, GÓMEZ VI AND HAMANN MI. 2019. Morphological variation of Aplectana hylambatis (Nematoda: Cosmocercidae) from different anuran hosts and localities in Argentina. An Acad Bras Cienc 91: e20171028. DOI. 10.1590/0001-3765201920171028.
\end{abstract}

\begin{abstract}
Aplectana hylambatis is a nematode with a wide geographic distribution and low host specificity. In spite of numerous reports, until this moment, the morphological variations between different hosts and localities have not been studied. We studied 401 specimens collected from five host species from seven localities in Argentina, and examined the following morphological characters: mamelon-like cuticular protuberances anterior to the vulva, structure of the gubernaculum and the spicules, number and arrangement of caudal papillae, and the measurements of twelve characters in females and eleven characters in males. The results showed that mamelon-like protuberances and caudal papillae varied in number and arrangement between different hosts and localities. The metrical study revealed that five characters in males and six in females contributed to variability; nine characters showed significant differences between host species and localities. Specimens of $A$. hylambatis collected from $R$. arenarum formed a group clearly differentiated from the rest of the specimens. The results from this study highlight the importance of examining as many specimens as possible from different host samples and from several localities to cover the intraspecific variations.
\end{abstract}

Key words: amphibians, cosmocercid nematodes, intraspecific variability, morphology.

\section{INTRODUCTION}

Intraspecific variation acts in the same way on all animals, both free-living (whether predators, herbivores or scavengers) or parasites. The general biological phenomena of natural selection, mutation, evolution, and adaptation applying to all groups of animals (Wharton 1957). Haley (1962) emphasised the obligatory of more studies on the frequency of intraspecific variations in parasitic

Correspondence to: Cynthya Elizabeth González

E-mail: cynthyaelizabethg@hotmail.com

ORCid: https://orcid.org/0000-0002-3512-9643 helminths as well as the nature of the factors that could influence these variations. This author reviews the factors that may cause variations in the morphological characteristics of helminths of the same species (e.g., host age and diet, number of parasites present, previous exposure to parasites, and presence of other parasites).

Variations in the presence/absence, form, number and type, arrangement, and measurements of different structures have been studied in numerous groups of organism. These variations have been well documented for different groups of parasites as protozoans (Reece et al. 2009, Mideo and Reece 
2012, Hussain et al. 2013), microsporidians (Vizoso and Ebert 2005), monogeneans (Matejusová et al. 2002, Mladineo et al. 2013, Brazenor et al. 2018), digeneans of invertebrates (Poulin 2003) and of vertebrates (Blankespoor 1974, Kohn et al. 1997, Hildebrant et al. 2015), cestodes (Barčák et al. 2014, Hanzelová et al. 2015, Benesh and Kalbe 2016), pentastomids (Kelehear et al. 2011, 2014), and mites (Downes 1990, Korallo-Vinarskaya et al. 2015), among others.

In reference to nematode parasites in general, Chitwood (1957) expressed that the influence of geographic and ecological factors have not been adequately explored to understand the development of species and their relationships. This author listed the factors that can influence variations in this group of helminths: size, age, physical condition, metabolic rate, and food supply on the part of the host; and the time of the penetration (first, second or subsequent infection) and the crowding of the specimens on the part of the nematodes. The variations in this group of helminths, in addition to responding to factors mentioned above, may also be the result of the different techniques used for their study (Chitwood 1957, Baker 1980, Perkins et al. 2011, Vhora and Bolek 2013). Subsequent to Chitwood (1957), numerous researches have studied the variability of nematode parasites in different groups of hosts (Michel et al. 1972, Fagerholm 1989, Suarez and Cabaret 1992, Viney and Diaz 2012, Gharamah et al. 2014, Catalano et al. 2015).

Specifically, morphological variations of parasitic helminths on anuran hosts have been studied in monogeneans (Tinsley and Jackson 1998, Vaira 2004) and in digeneans (Prokopic and Krivanek 1974, Kennedy 1980a, b, GrabdaKazubska and Combes 1981, León-Regàgnon et al. 1999, 2005). Few studies have been carried out into the variation of nematodes in different host species and different localities, and all of them have been done in the Northern hemisphere. Rhoden and
Bolek(2011) published morphological comparisons of adult females and males of Gyrinicola batrachiensis (Walton, 1929) from tadpoles of four species of anurans collected from four locations in Nebraska, U.S.A. Vhora and Bolek (2013) presented morphological comparisons of male and female Aplectana hamatospicula (Walton, 1940) with specimens studied from different hosts from Cuba, Mexico and the U.S.A.

Aplectana hylambatis was originally described as Oxysomatium hylambatis by Baylis (1927) from large intestine of Leptopelis aubryi (Duméril, 1856) (Anura: Arthroleptidae) from Guinea, Africa. In 1931, Travassos, in the review of the family Cosmocercidae (Railliet 1916 subfam.) Travassos (1925) separated specimens belonging to the genus Aplectana nematodes with small, rudimentary or absent gubernaculum and prodelph female reproductive system, and specimens belonging to the genus Oxysomatium specimens with long spicules, with or without gubernaculum, and amphidelphic female reproductive system. Baker (1980) re-described this species, based on specimens collected from Sclerophrys mauritanica (Schlegel 1841) (= Bufo mauritanicus) from Macenta, Guinea, and Rhinella achalensis (Cei 1972) (= B. achanlensis) from Cordoba, Argentina; this author stressed the presence of $A$. hylambatis on two continents, Africa and South America, separated by the Atlantic Ocean. Baker and Vaucher (1986) synonymised Oxysomatium bonariensis Gutiérrez 1945 collected from Rhinella arenarum (Hensel 1867) (= Bufo arenarum) from Argentina, and Aplectana pudenda, Masi Pallarés and Maciel (1974) collected from Rhinella schneideri (Werner 1894) (= Bufo paracnemis), Leptodactylus latrans (Steffen 1815) (= Leptodactylus ocellatus), Boana raniceps (Cope 1862) (= Hyla spegazzini) and Boana punctata (Schneider 1799) (= H. punctata) from Paraguay with A. hylambatis. Recently, in South America, A. hylambatis was collected from a wide range of hosts from Argentina, Ecuador, 
Guyana, Paraguay, Peru and Uruguay (see Campião et al. 2014), and in Brazil (Campião et al. 2016). Specifically, in Argentina, it was found in eight species of anuran amphibians, $R$. achalensis, $R$. arenarum, R. major (Müller and Hellmich, 1936), Leptodactylus latinasus (Jiménez de la Espada, 1875), L. chaquensis (Cei, 1950) L. bufonius (Boulenger, 1894) Physalaemus santafecinus (Barrio, 1965) and Trachycephalus typhonius (Linnaeus, 1758) (Draghi et al. 2015, González and Hamann 2015, Hamann and González 2015).

Despite wide geographic distribution and low host specificity presented by this species, the variations it presents in both morphological and metric character have not been analysed yet. The aim of this work was to study the variations in the selected morphological characteristics as number and arrangement of caudal papillae, shape of the spicules and the gubernaculum, the mamelon-like cuticular protuberances anterior to the vulva, and measurements of males and females of Aplectana hylambatis among different species of amphibians and localities in Argentina.

\section{MATERIALS AND METHODS}

\section{HOSTS AND NEMATODE PARASITES COLLECTION}

Two hundred and sixty-three amphibians belonging to five species, Dermatonotus muelleri (Boettger 1885) (Microhylidae), Rhinella major (Müller and Hellmich 1936), R. arenarum (Bufonidae), Leptodactylus bufonius Boulenger, 1894, and Physalaemus santafecinus (Leptodactylidae), of three families, were collected from seven different localities in Argentina. These localities belong to four different ecoregions: Chaco Seco, Chaco Húmedo, Monte de Sierras y Bolsones, and Pampa (Morello et al. 2012) (Table I).

Anurans were transported alive to the laboratory and then euthanised in chloroform $\left(\mathrm{CHCl}_{3}\right)$ following the recommendation of the ASIH/HL/SSAR Guidelines for the Use of Live
Amphibians and Reptiles as well as the regulations detailed in Argentinean National Law \#14346. At necropsy, hosts were sexed and the oesophagus, stomach, gut, lungs, liver, urinary bladder, kidneys, body cavity, and musculature skin examined for parasites. Amphibian taxonomy was following according to Frost (2018).

\section{MORPHOLOGICAL CHARACTERS STUDIED IN Aplectana hylambatis}

We examined 401 specimens (200 females and 201 males) of Aplectana hylambatis collected from the large intestine (number of total worms collected per host is presented in Table I). These nematodes were identified based on descriptions by Baker (1980) and Baker and Vaucher (1986). Nematodes were observed in vivo, counted, then fixed in $10 \%$ hot formaldehyde solution and preserved in $70 \%$ ethanol, cleared in lactophenol and examined as temporary mounts. Illustrations were made using a Leica microscope DM 2500 with the aid of a camera lucida. For detailed study, the number and arrangement of caudal papillae in males and mamelon-like cuticular protuberances anteriorly to vulva in females were examined by scanning electron microscopy (SEM). For SEM, nematodes were dehydrated through an ethanol series and an acetone series and then subjected to critical-point drying. Five males and five females were used per amphibian species and locality for the observation in the SEM. Specimens were coated with gold and examined using a Jeol 5800LV scanning electron microscope. The measurements are given in micrometers unless otherwise noted, as mean values $\pm \mathrm{SD}$, and a range provided in parentheses.

Morphological characters studied in male nematodes were: number and arrangement of caudal papillae, shape of spicule and gubernaculum, and measurements of eleven characters. The following measurements were recorded: total body length, greatest width, length and greatest width of oesophagus, length and greatest width of 


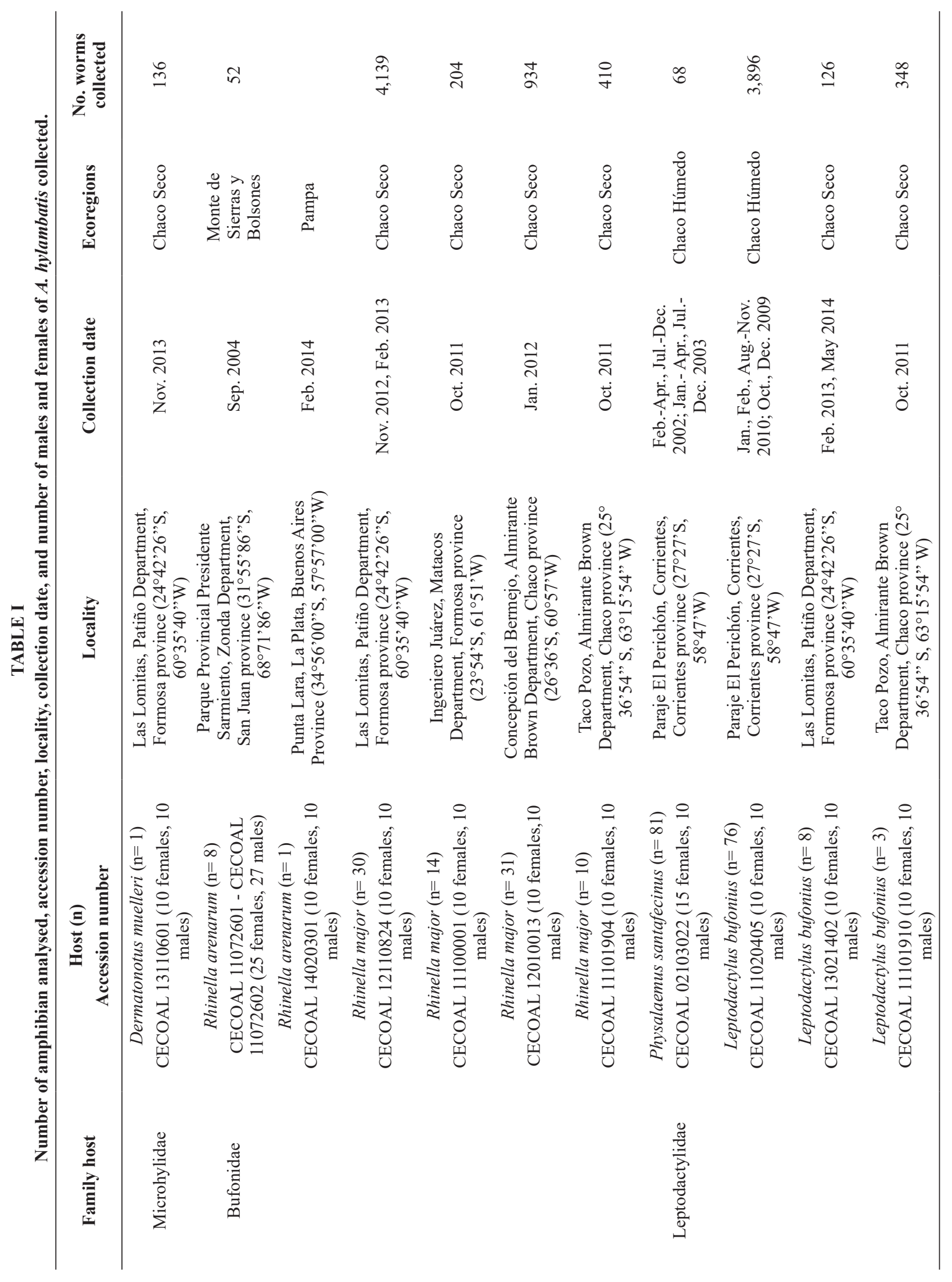


oesophageal bulb, distance of excretory pore from anterior end, distance of nerve ring from anterior end, distance from cloaca to posterior end at the extremity (tail length), length of spicule, and length of gubernaculum in lateral view.

The terms anus and cloaca in males have been used interchangeably by different authors (e.g. Ballesteros-Márquez 1945, R.O. Gutiérrez, unpublished data, Baker 1980: anus, Masi Pallarés and Maciel 1974, Vhora and Bolek 2013: cloaca). In present study, we use the term cloaca and papillae are classified in precloacal, adcloacal and postcloacal.

To study the number and arrangement of caudal papillae the following characters were considered (Figure 1): Precloacal papillae: two ventral parallel rows formed by papillae larger than somatic papillae. The distance between papillae of the same row was variable, but the distance between papillae of the same row generally decreases as they approach the cloaca (Figure 1a). Adcloacal papillae: divided into two groups-one group is ventral on the anterior lip of the cloaca and other group is lateral to the cloaca (Figure 1b, c). Lateral papillae located on each side of the cloaca: one pair slightly anterior or at the same level as the cloaca and another pair slightly posterior to the cloaca. The latter papillae similar in size to the precloacal papillae and were aligned with the precloacal papillae (Figure 1b). At the anterior lip of the cloaca the arrangement of papillae is $1+3$ : one large unpaired median papilla and 3 pairs located at the sides of the large unpaired papilla (three papillae on each side) (Figure 1c). Postcloacal papillae: located ventrally or laterally. We did not consider subdorsal papillae. Two large ventral pairs located close to each other approximately at the midregion of the tail. A variable number of pairs of small ventral and lateral papillae are located in the posterior half of the tail.

The morphology of the spicules and the gubernaculum were studied using a light microscope; in the spicules, the proximal end and the distal end were studied, specifically if the distal end presented fixed articulation (Figure 1d).

Morphological characters studied in female nematodes were: the mamelon-like cuticular protuberances anterior to the vulva, and measurements of twelve characters. The following measurements were recorded: total body length, greatest width, length and greatest width of oesophagus, length and greatest width of oesophageal bulb, distance of excretory pore from anterior end, distance of nerve ring from anterior end, distance of vulva from anterior end, distance of anus from posterior end (tail length), and length and width of eggs. Mamelon-like cuticular protuberances were counted and illustrated (Figure 1e, f). All studied females were mature, i.e. full of eggs and the eggs nearest to the vulva contained larvae.

Nematodes were deposited in the Helminthological Collection of the Centro de Ecología Aplicada del Litoral (CECOAL), Consejo Nacional de Investigaciones Científicas y Técnicas (CONICET), Corrientes city, Corrientes, Argentina; accession numbers presented in Table I.

\section{DATA ANALYSIS}

Principal component analysis (PCA) was used to estimate which variables were more important in relation to the total variance explained by each component. Twelve variables measured in females and eleven variables measured in males were entered into the PCA in order to assess the loading of each variable on the different components and their explained variance. With this ordination analysis, we reduced our multivariate data set into a smaller set of composite variables (principal components) with a limited loss of information (McGarigal et al. 2000). To test the null hypothesis of no difference between metric variables of males and females (dependent variables) and species 

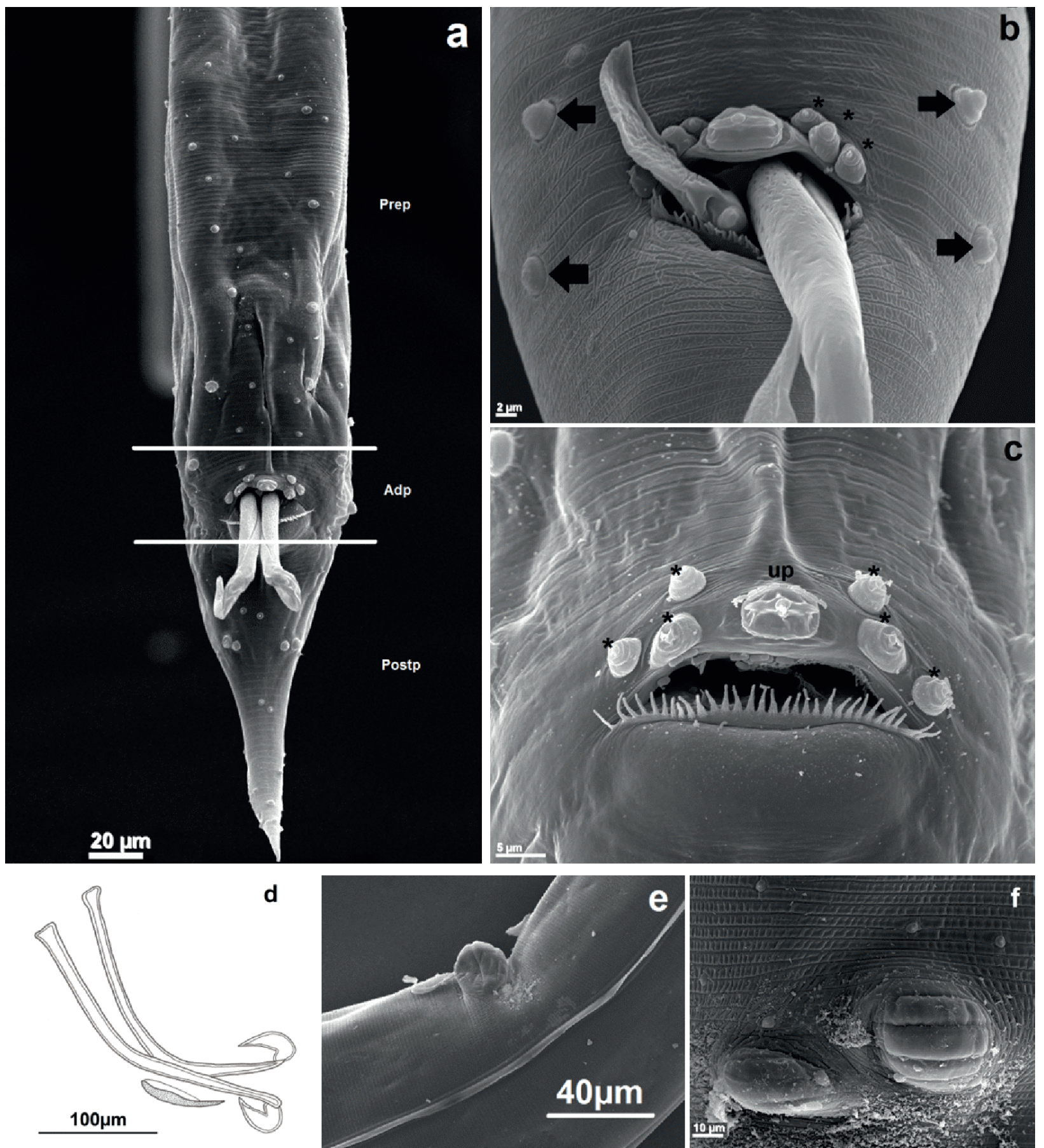

Figure 1 - Morphological characteristics of males and females of A. hylambatis studied in this study. (a) Posterior extremity in ventral view of male shows disposition of precloacal papillae (Prep), adcloacal papillae (Adp) and postcloacal papillae (Postp). (b) Detail of adcloacal papillae, arrows indicated lateral adcloacal papillae; asterisk indicated adcloacal papillae anterior to cloaca. (c) Disposition of adcloacal papillae in the anterior lip of cloaca; in the middle: large unpaired papilla (up), at each side of this, three papillae (3 pairs, asterisks). (d) Spicules and gubernaculum, lateral view. (e, f) Mamelon-like cuticular protuberances anteriorly to the vulva in lateral view (e), and in ventral view (f).

(a) and (c) collected from D. muelleri from Las Lomitas; (b) collected from R. major from Concepción del Bermejo; (d) collected from P. santafecinus from Corrientes; (e) collected from $R$. arenarum from San Juan; (f) collected in R. arenarum from La Plata. 
hosts and localities (factors), multivariate analysis of variance (MANOVA) was applied, including the more important components according to the PCA. In cases where the Wilk's lambda was significant, a two-factor ANOVA was performed for each variable with its respective a posteriori test (Tukey's test). Forward stepwise discriminant function analysis was used to determine which of selected variables in females and males best discriminate males and females nematodes from different hosts and localities. Prior to analysis, variables were logarithmically transformed $[\ln (\mathrm{x})]$ to fit a normal distribution. Analyses were performed using the software packages Xlstat 7.5 (Addinsoft 2017) and PAST 3.11 (Hammer et al. 2001).

\section{RESULTS}

Aplectana hylambatis (BAYLIS 1927) TRAVASSOS 1931. DESCRIPTION.

General: small, slender nematodes. Females of slightly greater length than males. Body cuticle with fine transverse striations. Lateral alae present in both sexes beginning at level of the nerve ring and ending at level of anus in females and at level of first precloacal papillae in males. Somatic papillae numerous and uniformly distributed. Mouth triangular with three lips, each of them with cuticular flap on anterior edge. Dorsal lip with two papillae; ventrolateral lip with one ventral papilla and one lateral amphid. Oesophagus divided into anterior pharyngeal portion, elongate corpus, short and narrow isthmus, and large valved bulb. Vulva postequatorial, with 1-3 mamelon-like cuticular protuberances located on anterior lip of vulva. Both ovaries located anterior to vulva. Posterior edge of cloaca in males with comb-like cuticular fringe. Caudal papillae of variable number and arrangement, divided in three groups: precloacal, adcloacal and postcloacal. Gubernaculum with ventral concavity and thickened lateral edges.
Spicules comparatively long with an articulation on the distal end.

MORPHOLOGICAL CHARACTERS IN RELATION TO DIFFERENT HOSTS AND LOCALITIES

\section{Caudal papillae}

In this study, the total number of caudal papillae was between 13 and 16 pairs. All examined specimens showed the typical three groups present in this species: precloacal, adcloacal and postcloacal papillae, with the large unpaired papilla anterior to the cloaca, but with some differences.

The number of precloacal papillae was between five pairs [in L. bufonius from Corrientes (Figure 2a), in L. bufonius from Las Lomitas (Figure 2b), and in $R$. major from Las Lomitas (Figure 2g)], and three pairs [in D. muelleri from Las Lomitas (Figure 2d), and P. santafecinus from Corrientes (Figure 2k)]; four pairs of precloacal papillae were present in six anuran hosts [in L. bufonius from Taco Pozo (Figure 2c), in R. major from Concepción del Bermejo (Figure 2e), in $R$. major from Ingeniero Juárez (Figure 2f), in $R$. major from Taco Pozo (Figure 2h), in R. arenarum from La Plata (Figure 2i) and in R. arenarum from San Juan (Figure 2j)]. In some specimens, such as those collected from D. muelleri from Las Lomitas and $R$. arenarum from La Plata (Figure 2d-i), between the two rows of precloacal papillae were two rows of somatic papillae of a size intermediate between the precloacal papillae and the somatic papillae of the rest of body; these papillae were not appreciable in specimens from other hosts or localities. As we mentioned above, the precloacal papillae of each row seemed to be continued by the lateral adcloacal papillae located each side of the cloaca.

Adcloacal lateral papillae were present in one pair [in L. bufonius from Las Lomitas (Figure 2b), in R. major from Las Lomitas (Figure 2g), and Taco Pozo (Figure 2h)], or in two pairs [in L. bufonius from Corrientes (Figure 2a), in L. bufonius from 
Taco Pozo (Figure 2c), in D. muelleri from Las Lomitas (Figure 2d), in R. major from Concepción del Bermejo (Figure 2e), and Ingeniero Juárez (Figure 2f), in $R$. arenarum from La Plata (Figure $2 \mathrm{i}$ ) and from San Juan (Figure 2j), and in $P$. santafecinus from Corrientes (Figure 2k)]. In cases when only single pair of adcloacal lateral papilla present, they were located approximately at the same level as the cloaca; when there were two pairs, the proximal one was located at the level of cloaca and the distal pair located posteriorly to cloaca at variable distance. Adcloacal papillae located at the anterior lip of the cloaca were present in all cases with the typical $3+1$ arrangement, except nematodes from L. bufonius from Corrientes; in this case, the specimens presented a $2+1$ arrangement (1 large unpaired papilla +1 pair on each side of this); also, in these specimens, one large unpaired papilla present at the posterior lip of cloaca, a character not observed in any of the other specimens.

Finally, the postcloacal papillae were between five and eight pairs. The most common number of postcloacal papillae was five pairs [L. bufonius from Las Lomitas (Figure 2b), R. major from Concepción del Bermejo (Figure 2e), from Ingeniero Juárez (Figure 2f), from Las Lomitas (Figure 2g) and from Taco Pozo (Figure 2h), and in P. santafecinus from Corrientes (Figure 2k)]; six pairs were present in four cases [L. bufonius from Corrientes (Figure 2a) and from Taco Pozo (Figure 2c), R. arenarum from La Plata (Figure 2i) and from San Juan (Figure 2j)]; only specimens collected from $D$. muelleri from Las Lomitas presented eight pairs of postcloacal papillae (Figure 2d). These postcloacal papillae were present in variable arrangements but the common character was the presence of two pairs of large ventral papillae approximately at the middle of the tail; these papillae where of a larger size than the rest of the postcloacal papillae. In some cases, such as in specimens from L. bufonius from Taco Pozo (Figure 2c), D. muelleri from Las Lomitas (Figure $2 \mathrm{~d}$ ), and $R$. arenarum from La Plata and from San Juan (Figure 2i, j) between these two pairs of papillae and the cloaca there was another pair of ventral papillae. The rest of the postcloacal papillae were located in the posterior half of the tail. In all cases this was one of a pair of papillae at the beginning of the posterior half of the tail; this pair was lateral in worms from L. bufonius from Corrientes (Figure 2a) and from Taco Pozo (Figure 2c), R. major from Ingeniero Juárez (Figure 2f) and from Taco Pozo (Figure 2h), and ventral in the rest of the specimens (see Figure 2b, d, e, g, i, j, k). In nematodes from L. bufonius from Las Lomitas (Figure 2b) and Taco Pozo (Figure 2c), R. major from Concepción del Bermejo (Figure 2e), from Ingeniero Juárez (Figure 2f), from Las Lomitas (Figure $2 \mathrm{~g}$ ) and from Taco Pozo (Figure 2h), $R$. arenarum from La Plata (Figure 2i) and from San Juan (Figure 2j), and P. santafecinus from Corrientes (Figure 2k), two pairs of small distal papillae were located very close to the posterior end; these pairs were one lateral and one ventral. In specimens from L. bufonius from Corrientes there was an additional lateral pair of papillae anterior to small distal papillae (Figure 2a). Finally, in nematodes from $D$. muelleri there were two additional ventral papillae anterior to the small distal papillae (Figure 2d).

The arrangements of caudal papillae for each host and locality are presented on Figure 2.

\section{SPICULES AND GUBERNACULUM}

In specimens of this study, the spicules and the gubernaculum did not show great morphological variation. In reference to spicules, they were long and had a distal end with a pointed tip and a proximal end with capitulum. The last portion possessed an articulation that, when the spicules are outside of worm, gives the appearance of a sickle or a hockey stick (Figure 1a, d). The gubernaculum was a well chitinised structure of oval shape, concave ventrally, and with thickened edges which developed further towards the distal end. Figure 

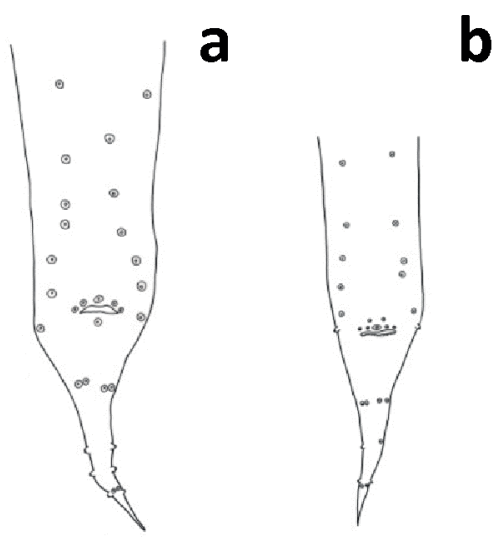

b

C

d

\section{5:4:6+1}

$5: 4: 5+1$
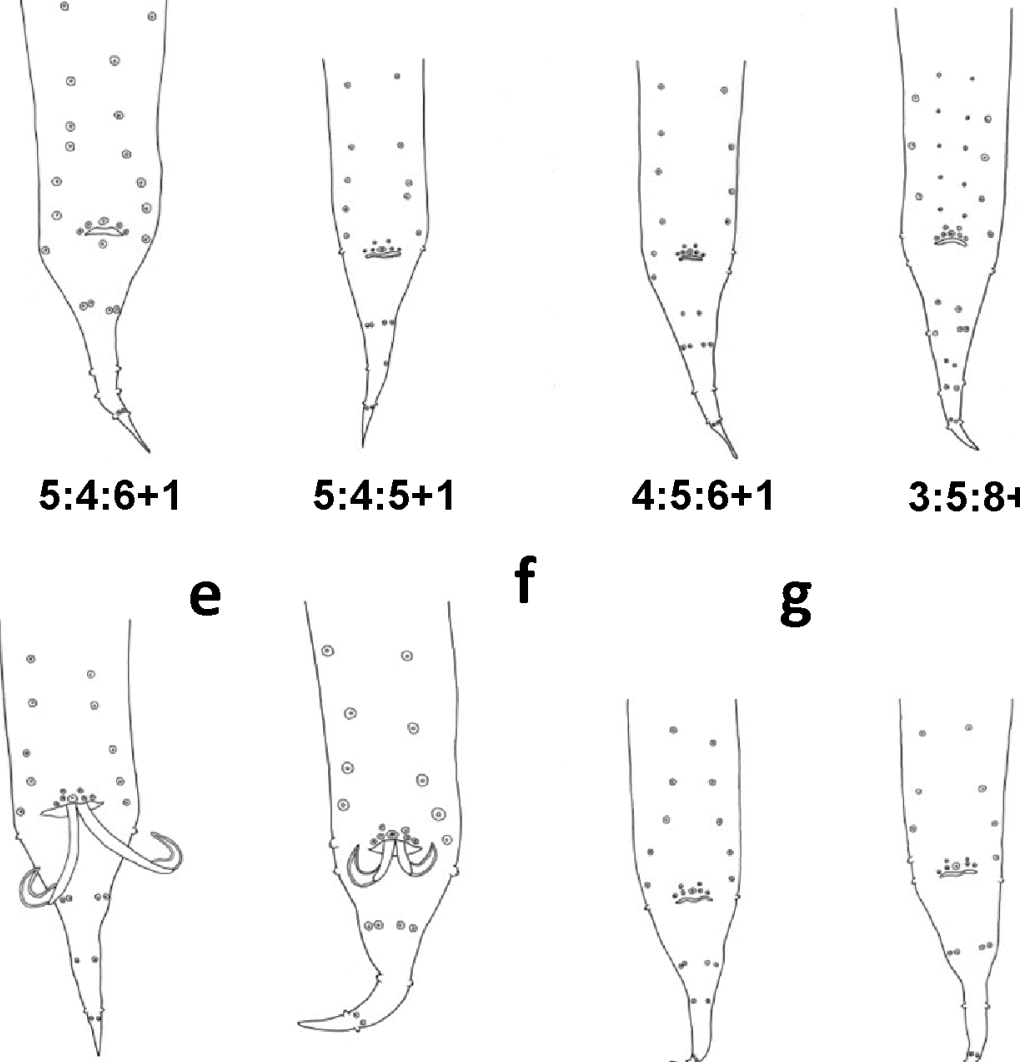

e

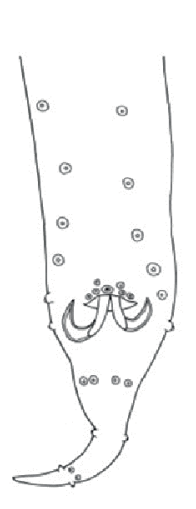

4:5:5+1

4:5:5+1

4:5:6+1

3:5:8+1

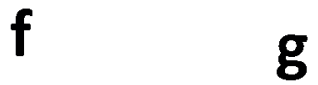

h

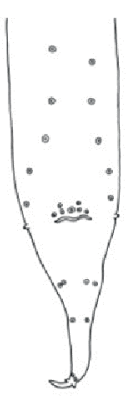

5:4:5+1

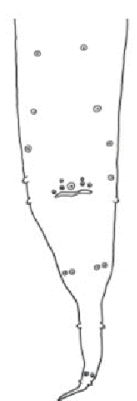

$4: 4: 5+1$

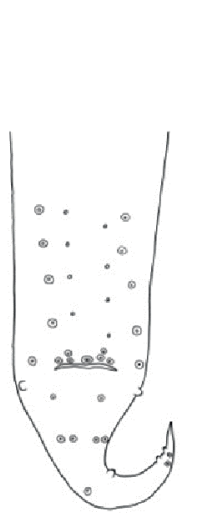

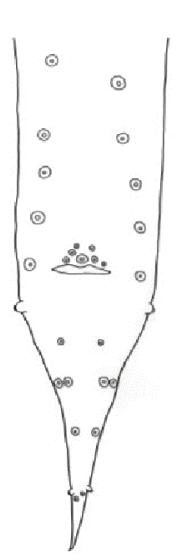

j

k

\footnotetext{
$4: 5: 6+1$

$4: 5: 6+1$

Figure 2 - Number and arrangement of caudal papillae of A. hylambatis from different amphibian hosts and localities in Argentina. (a) L. bufonius from Corrientes. (b) L. bufonius from Las Lomitas. (c) L. bufonius from Taco Pozo. (d) D. muelleri from Las Lomitas. (e) $R$. major from Concepción del Bermejo. (f) R. major from Ingeniero Juárez. (g) $R$. major from Las Lomitas. (h) $R$. major from Taco Pozo. (i) $R$. arenarum from La Plata. (j) $R$. arenarum from San Juan. (k) P. santafecinus from Corrientes.
} 

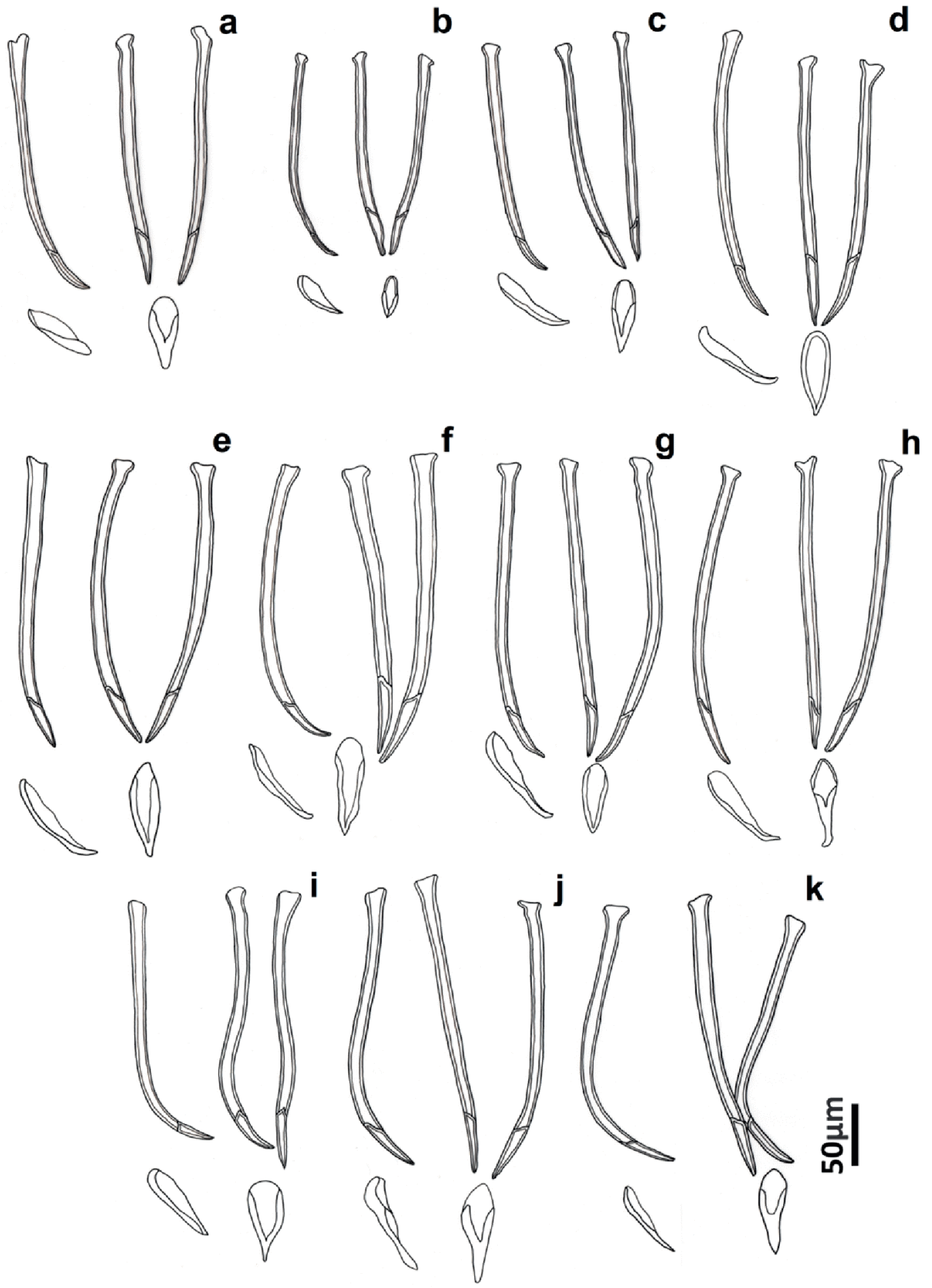

Figure 3 - Morphology of the spicules and the gubernaculum of A. hylambatis from different amphibian hosts and localities in Argentina. Spicules and gubernaculum are shown in lateral view (to the left of each figure) and in ventral view (to the right of each figure). (a) L. bufonius from Corrientes. (b) L. bufonius from Las Lomitas. (c) L. bufonius from Taco Pozo. (d) D. muelleri from Las Lomitas. (e) $R$. major from Concepción del Bermejo. (f) $R$. major from Ingeniero Juárez. (g) $R$. major from Las Lomitas. (h) $R$. major from Taco Pozo. (i) $R$. arenarum from La Plata. (j) $R$. arenarum from San Juan. (k) P. santafecinus from Corrientes. 
3a-k show the spicules and gubernaculum from specimens collected from different hosts and localities, in lateral and ventral view.

\section{MAMELON-LIKE CUTICULAR PROTUBERANCES}

In this study, the studied specimens presented variable numbers and dispositions of these structures (Figure 4a-k). Even some specimens collected in the same host and locality showed differences in the number and arrangement of mamelon-like protuberances.

Specimens collected from $L$. bufonius from Corrientes presented two large mamelon-like protuberances or three protuberances each partially covering the vulva (Figure 4a). Specimens collected from the same host but from Las Lomitas presented only one mamelon-like protuberance slightly displaced from the middle of the vulva or two protuberances, one on each extremity of the vulva (Figure 4b). Specimens collected from L. bufonius from Taco Pozo, and D. muelleri from Las Lomitas presented only one mamelon-like protuberance; this structure was very small and medial in specimens from L. bufonius (Figure 4c) and large slightly lateral in ones from D. muelleri (Figure 4d). Mamelon-like protuberances in specimens collected from $R$. major from Ingeniero Juárez numbered two, small, and located at each side of the vulvar aperture (Figure 4f). In specimens collected from $R$. major from Las Lomitas, we found one large and medial protuberance partially covering the vulva or two protuberances located at each extremity of the vulva without covering this structure (Figure $4 \mathrm{~g}$ ). Specimens collected from R. major from Taco Pozo presented either two protuberances slightly separated and not covering the vulva or slightly overlapping and covering partially the vulva (Figure $4 \mathrm{~h}$ ). In specimens collected from $R$. arenarum from La Plata, we observed a single medial mamelon-like protuberance, as well as specimens with two mamelon-like protuberances on each side of the vulva (Figure 4i). In specimens from the same host but collected in San Juan, we observed only one large and medial protuberance that partially covered the vulva (Figure 4j). Finally, in specimens from $P$. santafecinus this structure was small and medial, slightly separated from the vulva, or was large and medial, partially covering the vulva (Figure 4k).

\section{METRICAL CHARACTERS}

Measurements of all characters of male and female nematodes examined in this study are presented in Table II.

Table III shows the principal components and percentage of variance accounted by the morphometric variables of individuals of females of A. hylambatis $(\mathrm{n}=200)$. PC1 explained $50.41 \%$, and $\mathrm{PC} 217.0 \%$, of the variation (PC1 and $\mathrm{PC} 2$

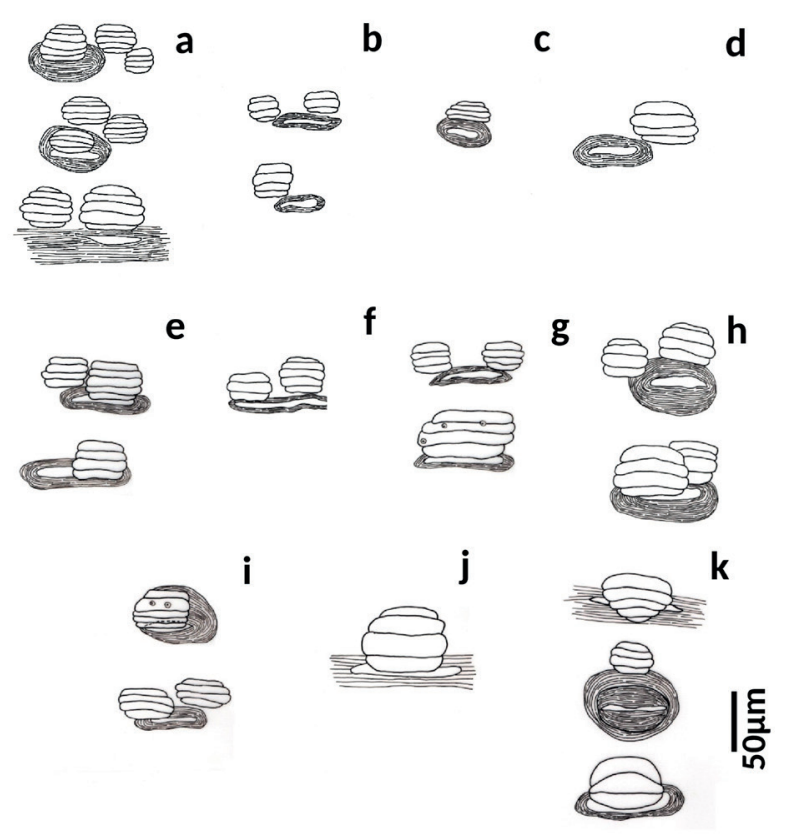

Figure 4 - Number and arrangement of mamelon-like structures to the vulva of $A$. hylambatis from different amphibian hosts and localities in Argentina. (a) L. bufonius from Corrientes. (b) L. bufonius from Las Lomitas. (c) L. bufonius from Taco Pozo. (d) D. muelleri from Las Lomitas. (e) R. major from Concepción del Bermejo. (f) R. major from Ingeniero Juárez. (g) $R$. major from Las Lomitas. (h) $R$. major from Taco Pozo. (i) $R$. arenarum from La Plata. (j) $R$. arenarum from San Juan. (k) P. santafecinus from Corrientes. 


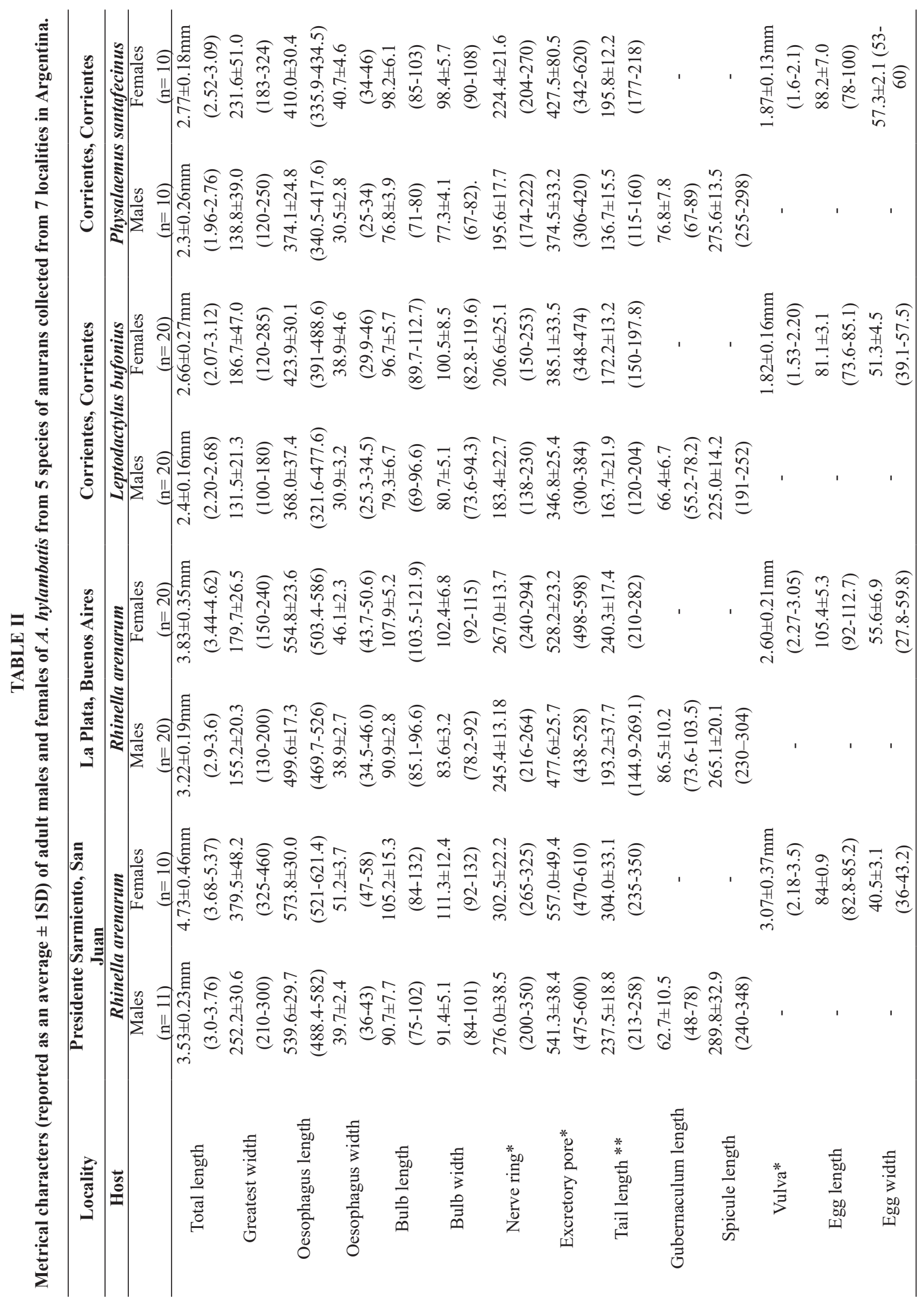




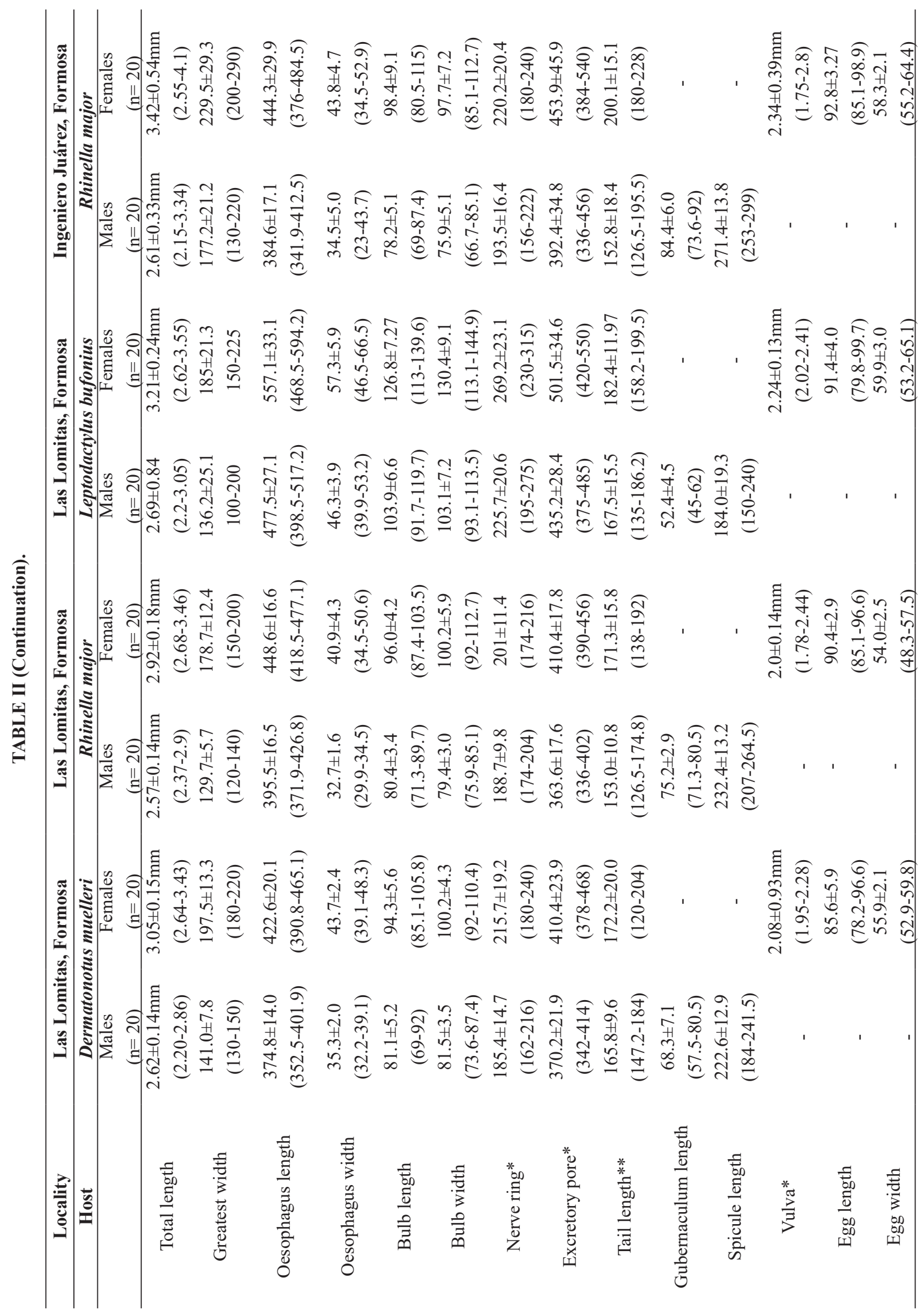




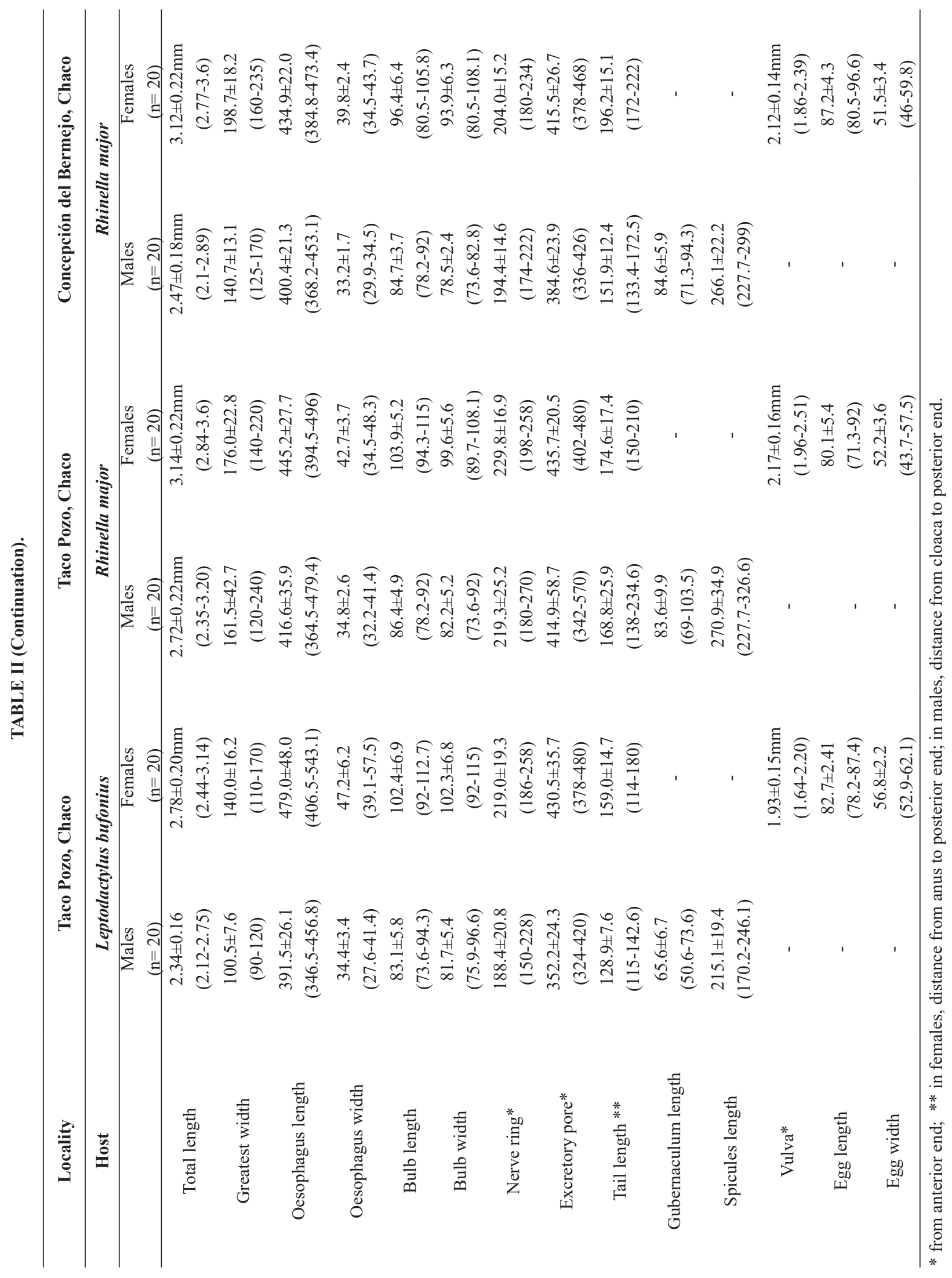


TABLE III

Results of a principal component analysis of morphometric variables of females of $\boldsymbol{A}$. hylambatis $(n=200)$ : Coefficients for standardized measurements and percentage of explained variation.

\begin{tabular}{lcc}
\hline & PC1 & PC2 \\
\hline Total length & 12.256 & 7.871 \\
Greatest width & 4.478 & 15.711 \\
Oesophagus length & 11.531 & 2.180 \\
Oesophagus width & 7.800 & 11.049 \\
Bulb length & 7.161 & 16.201 \\
Bulb width & 6.889 & 15.078 \\
Excretory pore* & 13.917 & 0.005 \\
Nerve ring* & 11.671 & 0.350 \\
Tail length & 7.924 & 13.817 \\
Vulva* & 12.558 & 5.677 \\
Egg length & 3.731 & 0.214 \\
Egg width & 0.085 & 11.846 \\
Eigenvalue & 6.049 & 2.041 \\
Percentage of total variance explained & 50.41 & 17.00 \\
Cumulative percentage & 50.41 & 67.41 \\
\hline
\end{tabular}

* from anterior end.

combined $=67.41 \%$ ). The first component reflected the influence of the distance of excretory pore from the anterior end, the distance of the vulva from the anterior end, and total length of body, while the second component reflected the influence of oesophageal bulb length, the greatest width of the body, and the bulb width. Table IV shows the principal components and percentage of variance accounted for the morphometric variables of individuals of males of $A$. hylambatis $(\mathrm{n}=201)$. PC1 explained $45.75 \%$, and PC2, $23.78 \%$, of the variation $(\mathrm{PC} 1$ and $\mathrm{PC} 2$ combined $=69.53 \%)$. The first component reflected the influence of distance of the excretory pore from the anterior end, total length of body, and the distance of nerve ring from the anterior end, while the second component reflected the influence of the length of spicule and gubernaculum.

A comparison of the host species and localities showed significant difference in morphometric variables in both sexes (females: hosts species:
TABLE IV

Results of a principal component analysis of morphometric variables of males of $\boldsymbol{A}$. hylambatis $(n=201)$ : Coefficients for standardized measurements and percentage of explained variation.

\begin{tabular}{lcc}
\hline & PC1 & PC2 \\
\hline Total length & 13.637 & 3.535 \\
Greatest width & 7.993 & 12.720 \\
Oesophagus length & 7.121 & 0.000 \\
Oesophagus width & 10.620 & 5.949 \\
Bulb length & 10.112 & 6.890 \\
Bulb width & 10.441 & 11.467 \\
Excretory pore* & 16.166 & 2.043 \\
Nerve ring * & 13.594 & 0.737 \\
Tail & 9.337 & 1.987 \\
Spicule length & 0.092 & 30.360 \\
Gubernaculum length & 0.886 & 24.312 \\
Eigenvalue & 5.033 & 2.616 \\
Percentage of total variance & 45.758 & 23.781 \\
explained & 45.758 & 69.539 \\
Cumulative percentage & & \\
\hline
\end{tabular}

* from anterior end.

MANOVA Wilks' Lambda $=0.025 ; \mathrm{F}_{6,200}=29.75$; $\mathrm{P}<0.05$; localities: MANOVA Wilks' Lambda $=$ $0.21 ; \mathrm{F}_{6,200}=14.92 ; \mathrm{P}<0.05$; males: host species: MANOVA Wilks' Lambda $=0.06 ; \mathrm{F}_{5,201}=38.29 ; \mathrm{P}$ $<0.05$; localities: MANOVA Wilks' Lambda $=0.24$; $\left.\mathrm{F}_{5,201}=12.73 ; \mathrm{P}<0.05\right)$. Females of $A$. hylambatis from different host species exhibited significant differences in all morphological comparisons except for total length and distance of vulva from anterior end; females of $A$. hylambatis from different localities exhibited significant differences in the six morphological characters (Table V). Males of $A$. hylambatis from different host species and from different localities showed significant differences in all morphological characters (Table VI).

The Tukey's post hoc test revealed significant differences in at least one morphological characteristic examined in females of $A$. hylambatis between all possible pairs of amphibian species (Table VII). All the four characters were significantly different in the case of $R$. arenarum $/ D$. 
TABLE V

Summary of one-way analysis of variance of females of A. hylambatis between morphological characters and anuran hosts and localities.

\begin{tabular}{lcccc}
\hline & \multicolumn{1}{c}{ Anuran host } & \multicolumn{1}{c}{ Locality } \\
\hline & $\boldsymbol{F}$ & $\boldsymbol{P}$ & $\boldsymbol{F}$ & $<0.0001$ \\
\hline Total length & $0.58_{9,199}$ & 0.62 & $14.5_{9,199}$ & $<0.0001$ \\
Greatest width & $10.23_{9,199}$ & $<0.0001$ & $51.8_{9,199}$ & $<0.0001$ \\
Bulb length & $32.46_{9,199}$ & $<0.0001$ & $13.72_{9,199}$ & $<0.0001$ \\
Bulb width & $34.83_{9,199}$ & $<0.0001$ & $21.41_{9,199}$ & $<0.0001$ \\
Vulva* & $0.27_{9,199}$ & 0.84 & $12.63_{9,199}$ & $<0.0001$ \\
Excretory pore* & $16.73_{9,199}$ & $<0.0001$ & $17.1_{9,199}$ & \\
\hline
\end{tabular}

* from anterior end.

TABLE VI

Summary of one-way analysis of variance of males of $\boldsymbol{A}$. hylambatis between morphological characters and anuran hosts and localities.

\begin{tabular}{lcccc}
\hline & \multicolumn{2}{c}{ Anuran host } & \multicolumn{1}{c}{ Locality } \\
\hline & $\boldsymbol{F}$ & $\boldsymbol{P}$ & $\boldsymbol{P}$ \\
\hline Total length & $3.31_{9,200}$ & 0.021 & $4.74_{9,200}$ & 0.0004 \\
Excretory pore* & $4.17_{9,200}$ & 0.007 & $7.96_{9,200}$ & $<0.0001$ \\
Nerve ring* & $5.24_{9,200}$ & 0.002 & $4.87_{9,200}$ & 0.0003 \\
Spicule length & $68.70_{9,200}$ & $<0.0001$ & $23.99_{9,200}$ & $<0.0001$ \\
Gubernaculum length & $65.68_{9,200}$ & $<0.0001$ & $30.06_{9,200}$ & $<0.0001$ \\
\hline
\end{tabular}

* from anterior end.

muelleri, L. bufonius/D. muelleri, and L. bufonius/R. major; in the case of $R$. arenarum/P. santafecinus and $R$. major/D. muelleri only one character was significantly different (greatest width and bulb length, respectively). In males of $A$. hylambatis as well as in females, the Tukey's post hoc test revealed significant differences in at least one morphological characteristic examined between all possible pairs of amphibian species (Table VIII). All five characters were significantly different in case of $R$. arenarum $/ R$. major and $R$. arenarum $/ L$. bufonius; in the case of $P$. santafecinus/R. major and $R$. major/D. muelleri only one character was significantly different (gubernaculum length and distance to nerve ring from anterior end, respectively).

Tables IX and X show the results of the Tukey's post hoc test between variables of males and females of $A$. hylambatis and the possible pairs of localities.
Females of $A$. hylambatis presented significant differences in at least one of the morphological characters studied. In males, significant differences were observed, in at least one of the morphological characters, between the different pairs of localities, except in the cases of Ingeniero Juárez/Concepción del Bermejo, Ingeniero Juárez/ Taco Pozo, and Taco Pozo/Concepción del Bermejo (Table X).

The results of the discriminant analysis of females of $A$. hylambatis by host species revealed that specimens collected from $R$. arenarum are more distinct from the others; also, specimens collected from L. bufonius form a group that separate from the rest but present a slight overlap with the specimens collected from the another hosts (Figure 5a). The same results were found in males of $A$. hylambatis from different amphibian hosts (Figure 5b). Figure 6a and 6b show the plot of linear discriminant analysis of females and 
TABLE VII

P values for pair comparisons of morphological features of females of A. hylambatis from different amphibian hosts in Argentina. Significant values in bold.

\begin{tabular}{lcccc}
\hline & Greatest width & Bulb length & Bulb width & Excretory pore* \\
\hline R. arenarum/D. muelleri & $<\mathbf{0 . 0 0 0 1}$ & $<\mathbf{0 . 0 0 0 1}$ & $<\mathbf{0 . 0 0 0 1}$ & $<\mathbf{0 . 0 0 0 1}$ \\
R. arenarum/R. major & $<\mathbf{0 . 0 0 0 1}$ & 0.096 & $<\mathbf{0 . 0 0 0 1}$ & $<\mathbf{0 . 0 0 0 1}$ \\
R. arenarum/L. bufonius & $<\mathbf{0 . 0 0 0 1}$ & 0.414 & 0.950 & $<\mathbf{0 . 0 0 0 1}$ \\
R. arenarum/P. santafecinus & $<\mathbf{0 . 0 0 0 1}$ & 0.538 & $<.878$ & 0.117 \\
P. santafecinus/D. muelleri & 0.690 & $<\mathbf{0 . 0 0 0 1}$ & $<\mathbf{0 . 0 0 0 1}$ & $<\mathbf{0 . 0 0 0 1}$ \\
P. santafecinus/R. major & 0.282 & $\mathbf{0 . 0 0 1}$ & $\mathbf{0 . 0 0 4}$ & $<\mathbf{0 . 0 0 0 1}$ \\
P. santafecinus/L. bufonius & $\mathbf{0 . 0 0 1}$ & 0.990 & 0.972 & $\mathbf{0 . 0 3 8}$ \\
L. bufonius/D. muelleri & $\mathbf{0 . 0 1 5}$ & $<\mathbf{0 . 0 0 0 1}$ & $<\mathbf{0 . 0 0 0 1}$ & $<\mathbf{0 . 0 0 0 1}$ \\
L. bufonius/R. major & $\mathbf{0 . 0 2 0}$ & $<\mathbf{0 . 0 0 0 1}$ & $<\mathbf{0 . 0 0 0 1}$ & $<\mathbf{0 . 0 0 0 1}$ \\
R. major $/ D$. muelleri & 0.918 & $\mathbf{0 . 0 0 2}$ & 0.087 & 0.204 \\
\hline
\end{tabular}

* from anterior end.

TABLE VIII

P values for pair comparisons of morphological features of males of $\boldsymbol{A}$. hylambatis from different amphibian hosts in Argentina. Significant values in bold.

\begin{tabular}{|c|c|c|c|c|c|}
\hline & Total length & $\begin{array}{c}\text { Excretory } \\
\text { pore* }\end{array}$ & $\begin{array}{l}\text { Nerve } \\
\text { ring* }\end{array}$ & Spicule length & $\begin{array}{c}\text { Gubernaculum } \\
\text { length }\end{array}$ \\
\hline R. arenarum/D. muelleri & $<0.0001$ & $<0.0001$ & $<0.0001$ & $<0.0001$ & 0.112 \\
\hline$R$. arenarum $/ R$. major & $<0.0001$ & $<0.0001$ & $<0.0001$ & $<0.0001$ & 0.0001 \\
\hline R. arenarum/L. bufonius & $<0.0001$ & $<0.0001$ & $<0.0001$ & $<0.0001$ & 0.002 \\
\hline$R$. arenarum/P. santafecinus & $<0.0001$ & $<0.0001$ & 0.015 & $<0.0001$ & 1.000 \\
\hline P. santafecinus/D. muelleri & 0.386 & 0.008 & 0.007 & 0.998 & 0.442 \\
\hline P. santafecinus/ R. major & 0.065 & 0.240 & 0.469 & 0.943 & 0.008 \\
\hline P. santafecinus/L. bufonius & 0.599 & 0.230 & 0.498 & $<0.0001$ & 0.002 \\
\hline L. bufonius/D. muelleri & 0.834 & 0.045 & 0.005 & $<0.0001$ & $<0.0001$ \\
\hline L. bufonius /R. major & 0.044 & 0.986 & 0.985 & $<0.0001$ & $<0.0001$ \\
\hline R. major/D. muelleri & 0.820 & 0.118 & 0.017 & 0.465 & 0.142 \\
\hline
\end{tabular}

* from anterior end.

males of $A$. hylambatis in seven different localities of this study. The analysis of the females of $A$. hylambatis by locality (Figure 6a) clearly shows a group consisting of the specimens collected in San Juan and other group consisting of the specimens collected in La Plata separated from the rest of localities. In case of males of $A$. hylambatis, a clear group formed by the specimens collected in San Juan is more dissimilar from those collected in the rest of the localities (Fig. 6b).

\section{DISCUSSION}

Although variations in the morphological characters of nematodes in particular, and of helminths in general, can be related to different factors of both the host and the environment (see Chitwood 1957, Haley 1962, Blankespoor 1974, Kennedy 1980a, b, León-Regàgnon et al. 1999, 2005, Poulin 2003, Perkins et al. 2011, Mladineo et al. 2013, Gharamah et al. 2014, Catalano et al. 2015, Hildebrant et 
TABLE IX

P values for pair comparisons of morphological features of females of $A$. hylambatis from different localities in Argentina. Significant values in bold.

\begin{tabular}{|c|c|c|c|c|c|c|}
\hline & Total length & Greatest width & Bulb length & Bulb width & Vulva* & Excretory pore* \\
\hline Ing. Juárez/La plata & $<0.0001$ & $<0.0001$ & 1.000 & 0.038 & $<0.0001$ & 0.015 \\
\hline Ing. Juárez/San Juan & 0.000 & $<0.0001$ & 0.995 & 0.627 & 0.001 & 0.008 \\
\hline Ing. Juárez/Taco Pozo & 0.000 & $<0.0001$ & 0.995 & 0.627 & 0.001 & 0.008 \\
\hline Ing. Juárez/Lomitas & 0.021 & 0.001 & 0.354 & 0.006 & 0.043 & 0.599 \\
\hline Ing. Juárez/Concepción & 0.123 & 0.035 & 0.993 & 0.705 & 0.083 & 0.028 \\
\hline Ing. Juárez/Corrientes & $<0.0001$ & 0.227 & 0.000 & 0.003 & $<0.0001$ & $<0.0001$ \\
\hline Corrientes/La Plata & 0.278 & $<0.0001$ & 0.002 & 1.000 & 0.937 & 0.088 \\
\hline Corrientes/San Juan & 0.007 & $<0.0001$ & $<0.0001$ & 0.016 & 0.001 & $<0.0001$ \\
\hline Corrientes/Taco Pozo & 0.007 & $<0.0001$ & $<0.0001$ & 0.016 & 0.001 & $<0.0001$ \\
\hline Corrientes/Las Lomitas & $<0.0001$ & 0.896 & $<0.0001$ & $<0.0001$ & $<0.0001$ & $<0.0001$ \\
\hline Corrientes/Concepción & 0.001 & 1.000 & 0.002 & 0.141 & 0.001 & $<0.0001$ \\
\hline Concepción/La Plata & $<0.0001$ & $<0.0001$ & 0.976 & 0.381 & 0.001 & 0.837 \\
\hline Concepción/San Juan & 0.619 & 0.000 & 1.000 & 1.000 & 0.891 & 1.000 \\
\hline Concepción/Taco Pozo & 0.619 & 0.000 & 1.000 & 1.000 & 0.891 & 1.000 \\
\hline Concepción/Las Lomitas & 0.999 & 0.965 & 0.072 & $<0.0001$ & 1.000 & 0.636 \\
\hline Las Lomitas/La Plata & $<0.0001$ & $<0.0001$ & 0.968 & $<0.0001$ & 0.000 & 0.146 \\
\hline Las Lomitas/San Juan & 0.658 & 0.000 & 0.006 & $<0.0001$ & 0.731 & 0.177 \\
\hline Las Lomitas/Taco Pozo & 0.658 & 0.000 & 0.006 & $<0.0001$ & 0.731 & 0.177 \\
\hline Taco Pozo/La Plata & $<0.0001$ & $<0.0001$ & 0.944 & 0.137 & 0.000 & 0.729 \\
\hline San Juan/La Plata & $<0.0001$ & $<0.0001$ & 0.944 & 0.137 & 0.000 & 0.729 \\
\hline
\end{tabular}

* from anterior end.

al. 2015, Benesh and Kalbe 2016, Brazenor et al. 2018), in this study, we show only variations occurring in A. hylambatis from five host species and seven localities without deep investigating of factors that produce them, which will be studied in further research.

In order to compare the morphological characters, we considered only those studies where morphological data for the species presented adequately, such as Baylis (1927), R.O. Gutiérrez (unpublished data), Masi Pallarés and Maciel (1974), Baker (1980), and Draghi et al. (2015). The great revisions of the family Cosmocercidae made by Travassos (1931) and Ballesteros-Márquez (1945) repeated the information of Baylis (1927).

Specimens examined in this study possessed a total of 13 to 16 pairs of caudal papillae; precloacal papillae varied between three and five, and postcloacal between five and eight. The common character in these specimens from different hosts and localities was the presence of a large unpaired papilla located on the anterior lip of the cloaca and a group of paired papillae on each side of it (two pairs in L. bufonius from Corrientes, and three pairs in all other cases). Precloacal and postcloacal papillae varied in number and arrangement.

Since its description in 1927, the morphological characteristics of $A$. hylambatis varied between different authors, especially as regarding the number of caudal papillae in males. Baylis (1927) referred to the number and arrangement of precloacal and postcloacal papillae but not to the adcloacal papillae located at the anterior lip of the cloaca. This author established 'apparently' five pairs of preanal papillae and six pairs of postanal papillae; of these three pairs are subventral and grouped 
TABLE X

P values for pair comparisons of morphological features of males of $A$. hylambatis from different localities in Argentina. Significant values in bold.

\begin{tabular}{|c|c|c|c|c|c|}
\hline & Total length & Excretory pore* & Nerve ring* & Spicule length & Gubernaculum length \\
\hline San Juan/La Plata & 0.073 & 0.009 & 0.405 & 0.088 & $<0.0001$ \\
\hline San Juan/Concepción & 0.011 & 0.945 & 0.646 & $<0.0001$ & $<0.0001$ \\
\hline San Juan/Corrientes & 0.225 & $<0.0001$ & 0.002 & $<0.0001$ & $<0.0001$ \\
\hline San Juan/Taco Pozo & 0.391 & 0.366 & 0.988 & $<0.0001$ & $<0.0001$ \\
\hline San Juan/Ing. Juárez & 0.770 & 1.000 & 0.533 & $<0.0001$ & $<0.0001$ \\
\hline Las Lomitas/La Plata & 0.073 & 0.009 & 0.405 & 0.088 & $<0.0001$ \\
\hline Las Lomitas/Concepción & 0.011 & 0.945 & 0.646 & $<0.0001$ & $<0.0001$ \\
\hline Las Lomitas/Corrientes & 0.225 & $<0.0001$ & 0.002 & $<0.0001$ & $<0.0001$ \\
\hline Las Lomitas/Taco Pozo & 0.391 & 0.366 & 0.988 & $<0.0001$ & $<0.0001$ \\
\hline Las Lomitas/Ing. Juárez & 0.770 & 1.000 & 0.533 & $<0.0001$ & $<0.0001$ \\
\hline Ing. Juárez/La Plata & 0.837 & 0.149 & 0.999 & $<0.0001$ & 0.004 \\
\hline Ing. Juárez/Concepción & 0.495 & 0.996 & 1.000 & 0.982 & 1.000 \\
\hline Ing. Juárez/Corrientes & 0.993 & 0.006 & 0.649 & 0.827 & 0.754 \\
\hline Ing. Juárez/Taco Pozo & 1.000 & 0.895 & 0.873 & 1.000 & 0.998 \\
\hline Taco Pozo/La Plata & 0.804 & 0.434 & 0.829 & $<0.0001$ & 0.005 \\
\hline Taco Pozo/Concepción & 0.467 & 0.998 & 0.933 & 0.995 & 0.999 \\
\hline Taco Pozo/Corrientes & 0.984 & 0.007 & 0.014 & 0.417 & 0.812 \\
\hline Corrientes/La Plata & 0.987 & 1.000 & 0.975 & $<0.0001$ & 0.145 \\
\hline Corrientes/Concepción & 0.979 & 0.029 & 0.562 & 0.401 & 0.794 \\
\hline Concepción/La Plata & 1.000 & 0.334 & 0.998 & $<0.0001$ & 0.005 \\
\hline
\end{tabular}

* from anterior end.

close together in the cloacal region, one pair (the second from the posterior end) is subdorsal and the rest are subventral. So, the arrangement of these pairs of papillae is 5:0:6.

R.O. Gutiérrez (unpublished data) referred to precloacal papillae as median (3-4 pairs) and lateral (1 pair), adcloacal papillae as one pair lateral located at the level of cloaca, postcloacal papillae as one large pair at the mid-region of the tail, and two small pairs in the distal part of tail. This author also referred to the existence of small papillae with variable disposition; some of them are precloacal (see his Figure 3: clearly these are somatic papillae located between precloacal papillae); pericloacal (in its Figure 3: one pair on the anterior lip of cloaca, and between them one median papilla, one pair on the posterior lip of cloaca and one pair of small papillae at the same level as cloaca), and postcloacal papillae (see his Figure 3: two ventral pairs near the cloaca, one large and two small pairs in the middle region of the tail, and two small ventral pairs at the posterior third of the tail). This author referred to the existence of the adcloacal papillae anterior to cloaca but did not express the number; however, it can be established by the drawing (Figure 3) that the number is three: one median papilla and two on each side of this. For most of these papillae author did not express the number; the number of pairs of papillae was established according to Figure 3 . So, the arrangement of these pairs of papillae is $4-5: 4: 7+1$. In this case, we must remember the existence of unpaired papillae located in the posterior lip of the cloaca, which is not expressed in the arrangement. 

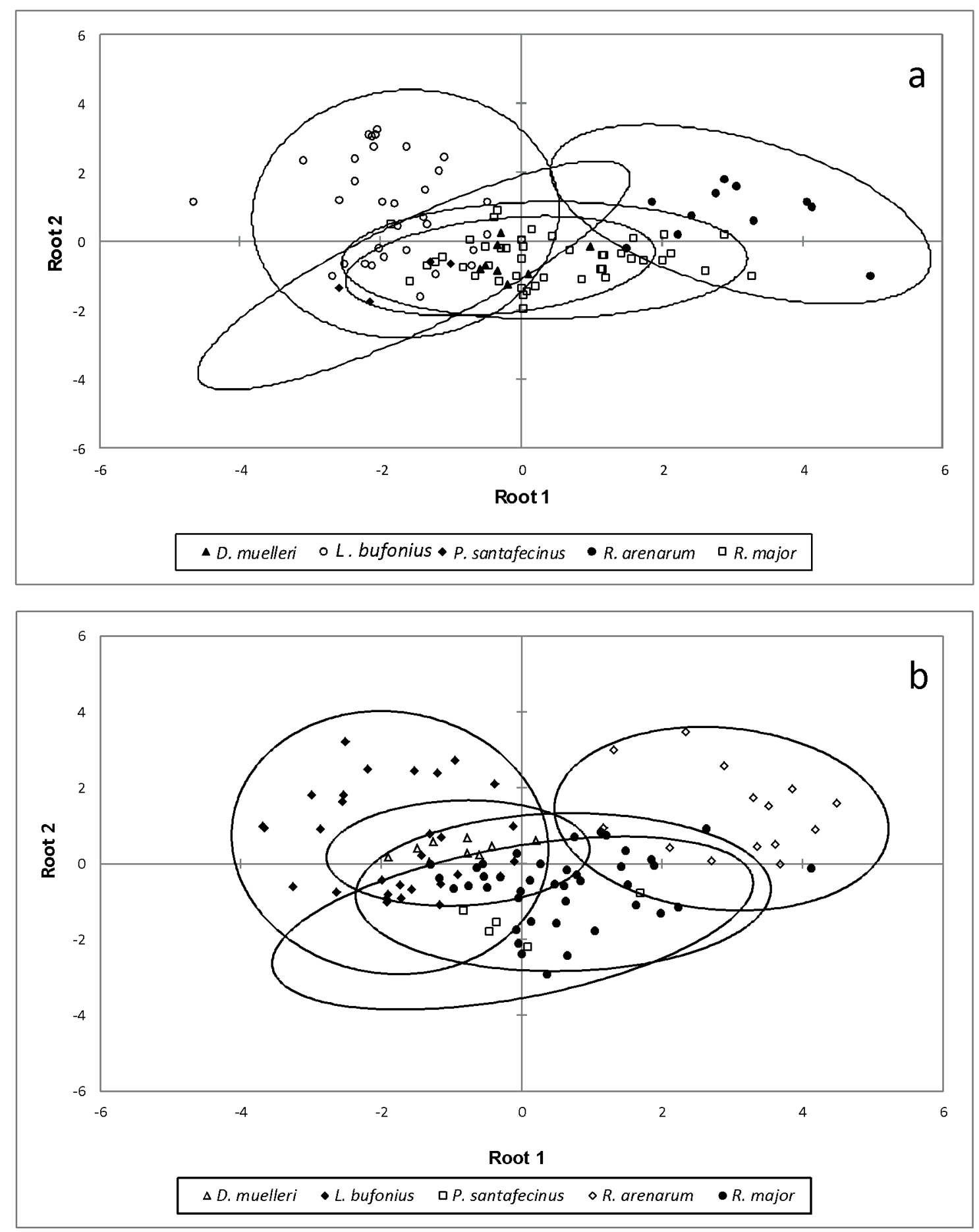

Figure 5 - (a) Plot of the 200 females specimens of the five host of Aplectana hylambatis against the first and second discriminant functions resulting from Linear Discriminant Analysis conducted with six variables (see text for explanation). The first two discriminant functions of the model accounted for $90.34 \%$ of the total variation among samples, cumulatively. Ellipses represent 95\% confidence intervals. (b) Plot of the 201 males specimens of the five host of Aplectana hylambatis against the first and second discriminant functions resulting from Linear Discriminant Analysis conducted with five variables (see text for explanation). The first two discriminant functions of the model accounted for $93.28 \%$ of the total variation among samples, cumulatively. Ellipses represent $95 \%$ confidence intervals. 

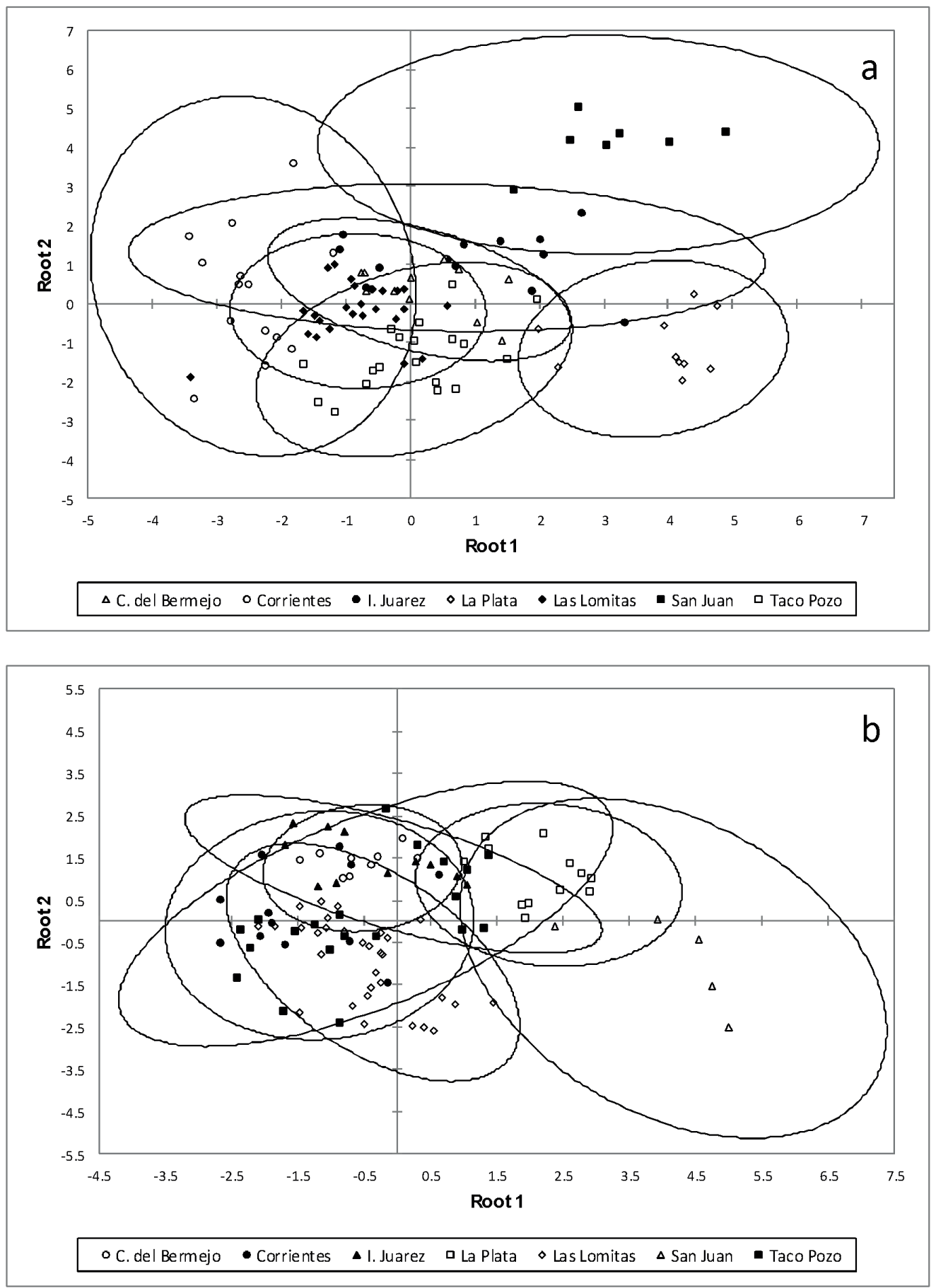

Figure 6 - (a) Plot of the 200 females specimens of the seven localities of Aplectana hylambatis against the first and second discriminant functions resulting from Linear Discriminant Analysis conducted with six variables (see text for explanation). The first two discriminant functions of the model accounted for $91.48 \%$ of the total variation among samples, cumulatively. Ellipses represent $95 \%$ confidence intervals. (b) Plot of the 201 males specimens of the seven localities of Aplectana hylambatis against the first and second discriminant functions resulting from Linear Discriminant Analysis conducted with five variables (see text for explanation). The first two discriminant functions of the model accounted for $82.94 \%$ of the total variation among samples, cumulatively. Ellipses represent $95 \%$ confidence intervals. 
Masi Pallarés and Maciel (1974) established the existence of seven pairs of precloacal papillae; of these, two pairs are lateral, and five pairs ventrolateral. However, as can be seen in Figure 2 of the work of these authors, the most distal pair of lateral papillae corresponds to the large adcloacal papillae located at the same level as the cloaca in the studies of Baker (1980) and R.O. Gutiérrez (unpublished data). Also, they established three pairs of adcloacal papillae on the anterior lip of the cloaca and one large median unpaired papilla between them. In respect of the postcloacal papillae, seven pairs were listed in this work: two large ventral pairs at the middle of the tail, one small lateral pair close to the anterior pairs, and four small lateral pairs in the distal half of the tail. Thus, the arrangement of these pairs of papillae is $6: 4: 7+1$.

In his re-description of $A$. hylambatis, Baker (1980) listed pairs of caudal papillae as follows: 'five large pre-anal subventral pairs, one large sublateral ad-anal pair; one large unpaired and three pairs on anterior lip of anus; two large subventral pairs located close together in mid-region of tail; posterior half of tail with subdorsal pair, two lateral pairs and one subventral pair of small papillae'. Therefore, in this case, the arrangement of these pairs of papillae is $5: 4: 6+1$.

Finally, Draghi et al. (2015) established the following pattern of papillae: $3-4: 4: 3+1$; i.e., the three pairs of postcloacal papillae are two ventrolateral in position and located in the median region of tail, and one pair next to the posterior end.

In these previous reports, the total pairs of caudal papillae varied between 10 and 17; precloacal papillae varied from 3 to 6 pairs, and postcloacal papillae varied from 3 to 7 pairs. Except for Baylis (1927), all the afore mentioned authors found four pairs of adcloacal papillae and one large unpaired papilla anterior to the cloaca. It is possible that the absence of these papillae in the work of Baylis (1927) is an involuntary omission by the author.
Spicules and gubernaculum in this study presented uniformity in terms of morphology regardless of examined hosts and geographical location. Baylis (1927) described the spicules as structures with 'striking peculiarity': the distal end of each one is encased in a hyaline sheath with hook-like appearance, and in reference to the gubernaculum, expressed that this part is large and well chitinised. Travassos (1931), Lent and Freitas (1948), and Baker (1980) expressed, as Baylis done previously (1927), that the spicules are covered at their distal end by a hyaline membrane; the gubernaculum was described as large and well chitinised. R.O. Gutiérrez (unpublished data) described the spicules as equal, and possessing at $1 / 8$ of the total length, a fixed articulation that divided the spicules into two unequal parts. MasiPallarés and Maciel (1974) agreed with this author and expressed that the spicule, in its distal region, showed an articulated portion, and that when the distal end of the spicule was everted had the appearance of a 'hockey stick'. No particularity was reported by these authors for the gubernaculum. For the spicule, we believe, as did R.O. Gutiérrez (unpublished data) and Masi-Pallarés and Maciel (1974), that its distal end has an articulation that allows us to observe the typical form of 'hook'. This was observed both under an optical microscope and a scanning microscope. In addition, although the spicules are within the body of male, mentioned articulation can be observed as a very marked diagonal line at approximately $1 / 8$ of the total length (Figure 3a-k). The gubernaculum in all cases presented sheet form with a ventral concavity and more pointed towards the distal extremity.

Finally, the third morphological character studied in this work, the mamelon-like cuticular protuberances anterior to the vulva, did not present uniformity in size, number or arrangement. Numbers varied between one and three, and the arrangement of each protuberance was very variable (Figure 4ak). Baylis (1927), in the description of the species, 
did not refer to these structures.R.O. Gutiérrez (unpublished data) referred to the existence of only one external chitinous piece located anterior to the vulva. Masi Pallarés and Maciel (1974) found two processes well sclerotised on the edge of the anterior lip of vulva, like rosettes; these structures had very small papillae. In the re-description, Baker (1980) established that the vulva is surrounded by $2-3$ mamelon-like cuticular protuberances (in Figure 6a, one of these structures possesses small papillae). Compared by host and by locality, this characteristic of the females of $A$. hylambatis did not show a definite pattern, as the caudal papillae of the males.

Therefore, the morphology of the spicules and gubernaculum, and number and arrangement of mamelon-like protuberances, did not present a clear pattern that referred to a group of hosts or to certain localities. However, if the number and arrangement of the caudal papillae is compared, the results show that considering the host species, specimens collected from $R$. major presented, in all cases, five pairs of postcloacal papillae, whereas precloacal and adcloacal papillae varied from 4-5 pairs. Specimens collected from $R$. arenarum presented the same number and the same arrangement of caudal papillae; the only difference was the presence of two additional medial rows of precloacal papillae in specimens from $R$. arenarum from La Plata. Specimens collected from $L$. bufonius differed in number and arrangement of caudal papillae. The clearest difference was the presence of only four paired papillae anterior to the cloaca, and the unpaired papillae in the posterior lip of the cloaca in specimens from Corrientes. Specimens collected in D. muelleri (as ones collected in $R$. arenarum from La Plata) presented two rows of papillae clearly distinguished from somatic papillae by the size between the rows of precloacal papillae; moreover, these specimens presented a greater number of caudal papillae, with a total of 16 pairs. Finally, specimens collected from P. santafecinus from Corrientes presented only 13 pairs of caudal papillae (as those collected in R. major from Taco Pozo).

Examined by locality, specimens from localities that correspond to ecoregions of Chaco Seco (Ingeniero Juárez, Taco Pozo, Las Lomitas, Concepción del Bermejo) and Chaco Húmedo (Corrientes) present a wide variation in the number and arrangement of caudal papillae, without a clearly defined pattern. Nevertheless, the specimens collected in La Plata (Pampa ecogerion) and San Juan (Monte de Sierras and Bolsones ecoregion) showed the same number and arrangement of caudal papillae. It is noteworthy that in the last two ecoregions the specimens of $A$. hylambatis were collected from $R$. arenarum.

The number of caudal papillae and spicule morphology are the most significant distinguishing characteristics for species identification in the genus Aplectana (Bursey et al. 2006, Vhora and Bolek 2013). In our study, in addition to these two characteristics, we examined the shape of the gubernaculum and the number and arrangement of the cuticular protuberances anterior to the vulva in females. We found that two of these characters (the number and disposition of the caudal papillae and the cuticular protuberances anterior to the vulva) in general, show a great morphological variability within specimens collected from different hosts and localities of Argentina. This is consistent with previous studies conducted in the Neotropical and Ethiopian regions in different hosts as detailed above. The morphology of the spicules and the gubernaculum were very uniform in all studied specimens.

Considering simultaneously these three morphological characters studied no pattern of clustering by host or locality was obtained. However, it should be noted that the specimens collected in localities La Plata and San Juan that from the same host, $R$. arenarum, presented the same number and distribution of caudal papillae in males. 
Other species of Aplectana also showed variability in their morphological characters. Probably the most studied species was $A$. macinthoshii (Stewart 1914) Travassos 1931. That species has wide geographical distribution and was collected from numerous host species. This cosmocercid presents a wide variation in the disposition and number of the caudal papillae in the males but also in other characters such as number and arrangement of cephalic papillae, gubernaculum, spicules, female tail, and lateral alae, even in the same host species at the same site of collection (see Yuen 1965, Baker 1980). In the Neotropical realm, Dyer (1990) considered the differences in the number and arrangement of caudal papillae of A. travassosi (Gomes and da Motta 1967) Baker, 1980 between specimens from Ecuador and from Brazil studied by Gomes and da Motta (1967) as intraspecific variations.

The comparison of metrical characteristics of females and males of $A$. hylambatis indicated that this species, in general, showed little variability between different amphibian hosts and localities in Argentina. Of all the characters measured in both sexes, six in females and five in males contributed to this variability (see Tables III and IV), including the length of spicules in males. At this point, Vhora and Bolek (2013) suggested that the spicule size is more useful for species identification of the genus Aplectana than the length and width of typical nematode measurements. Moreover, some keys for the identification of species of the genus Aplectana use the length of the spicule and the gubernaculum for the species differentiation (Baker 1980, Piñeiro Gómez et al. 2017).

Rhoden and Bolek (2011) researched a pharyngodonid nematode, Gyrinicola batrachiensis (Walton, 1929) Adamson, 1981 in tadpoles of eight species of amphibian from five locations in Nebraska. These authors found that female nematodes from different species of hosts presented significant differences in all morphological character except for four (oesophageal bulb length, egg length, distance to vulva from anterior end, and total body length); distance of vulva from anterior end and total length of studied herein female nematodes also did not present significant differences between hosts. In males from different hosts, Rhoden and Bolek (2011) found significant differences in all characters except for four (pharyngeal bulb length and width, and distance to nerve ring and excretory pore from anterior end); in our study, male nematodes from different hosts showed significant differences in all cases.

On the other hand, females and males of $A$. hylambatis differed in metric characters between the different host species; in some cases, with a greater degree of dissimilarity (e.g. $R$. arenarum $/ D$. muelleri, L. bufonius/D. muelleri, and L. bufonius/R. major in the case of females, and $R$. arenarum $/ R$. major, and $R$. arenarum/L. bufonius in the case of males; Tables VII and VIII). In our opinion, in case of females, this dissimilarity might be explained by more distant phylogenetic relationship of hosts (bufonid, microhylid, and leptodactylid). Similarly, Vhora and Bolek (2013) found clear differences in specimens of $A$. hamatospicula from microhylid, bufonid and hylid hosts. The case of males is more difficult to explain because one pair of amphibian species where the males of $A$. hylambatis present a great dissimilarity are congeneric species $(R$. arenarum and $R$. major).

By locality, in general, males and females of A. hylambatis were morphometric different between different collection sites. These results are similar to Vhora and Bolek (2013) who found that A. hamatospicula from Oklahoma comparing with previous reports from Mexico and Cuba, were morphologically different. In our study, in the case of males, greater similarity may be observed between specimens collected from Ingeniero Juárez, Concepción del Bermejo and Taco Pozo than between those from other localities (Table X). 
The discriminant analyses summarized the findings expressed above. The males of $A$. hylambatis collected from $R$. arenarum had an arrangement of caudal papillae with the following pattern: 4: 5: $6+1$ and clearly separated from the rest of the males collected from the other hosts. By locality, specimens collected in localities belonging to the Chaco Seco, Chaco Húmedo and Pampa ecoregions, form a clearly related group; however, within this group, the specimens collected in the locality of La Plata (Pampa ecoregion) are separated from those collected in the localities belonging to the other ecoregions. Clearly, specimens collected from San Juan (Montes and Bolsones ecoregion) were more dissimilar comparing to the rest of localities. In case of females, specimens collected from $R$. arenarum and from San Juan (Montes and Bolsones ecoregion) and La Plata (Pampa ecoregion) are more dissimilar comparing to specimens from other hosts and localities.

This study, in agreement with previous investigations (Vhora and Bolek 2013, Rhoden and Bolek 2011), indicates that different species of host from different localities can induce morphological variations in nematodes parasitizing amphibian.

In any case in different genus of Cosmocercidae, the importance of developing molecular studies is undeniable. This will allow to elucidate, if they are cryptic species that are geographically separated.

\section{GENERAL CONSIDERATIONS}

Aplectana hylambatis is a species easily identifiable by two morphological characters: 1) the possession of the spicule having specific shape when extending out of the body worm and 2) the possession of three pairs of adcloacal papillae on the anterior lip of the cloaca, with a large unpaired papilla between them.

In this study, we found that morphological characters, such as the number and arrangement of precloacal, adcloacal and postcloacal caudal papillae, as well as number and arrangement of cuticular protuberances anterior to the vulva, vary in nematodes from different host species and localities in Argentina. For five host species from seven different localities in Argentina, the precloacal papillae ranged from 3 to 5 pairs (always ventral), adcloacal papillae between 4 and 5 pairs (of these, 1 to 2 pairs are lateral to the cloaca), and the postcloacal papillae from 5 to 8 pairs (varying in disposition for papillae located in the posterior half of tail: ventral-lateral). The cuticular protuberances anterior to the vulva ranged from 1 to 3 in different locations. The morphology of the spicule and gubernaculum did not present variations between the different hosts and localities. The length of the spicules and the gubernaculum in males, as previously studied in cosmocercids, were significant in the metric analysis.

In general, the metric characters of this cosmocercid nematode presented variations, whether taking into account the localities or the host species, except for males from three localities in Chaco Seco.

Nevertheless, in spite of these variations, the specimens of $A$. hylambatis collected in $R$. arenarum form a group clearly differentiated from the rest of specimens collected from the rest of the hosts. Males and females of this cosmocercid presented the highest values of most of metric characters analysed, and males showed the same pattern of caudal papillae $(4: 5: 6+1)$. If we add the data of discriminant analysis by locality showing the separation of the specimens collected in San Juan, we can conclude that males and females of $A$. hylambatis of the Monte and Bolsones ecoregion form a separate group of specimens from those collected from the rest of the hosts and sampled locations. The other group is composed of the specimens of $A$. hylambatis collected in Buenos Aires, Chaco, Formosa and Corrientes provinces, which belong to the ecoregions Pampa, Chaco Húmedo and Chaco Seco, but at this point it should be noted that the specimens collected in La Plata 
(Pampa ecoregion) were clearly different from the rest of the nematodes collected in the Chaco Húmedo and Chaco Seco ecoregions.

Therefore, although the Argentinean specimens of A. hylambatis show some variations in morphology regarding the host species and locality, they can be grouped into specimens collected from $R$. arenarum in the Bolsones and Montes ecoregion and specimens collected from the rest of the hosts in Chaco Húmedo, Chaco Seco and Pampa ecoregions. Thus, presented variability might be caused by the distance that separates the analysed populations (i.e., geographical factor).

As previously supposed, the number of caudal papillae is one of the most significant features for the identification of species of the genus Aplectana. It should be taken with caution, due to the great variability in both number and disposition they present. Some species, such as A. hylambatis, are easily identifiable by characters such as the morphology of the distal end of the spicules, but not all species of the genus have features as remarkable as this.

This study shows only, as a first step, the morphometric variations of $A$. hylambatis in different anuran hosts from different localities in Argentina. A more complete study should include factors such as age, size, diet, physiological condition, and metabolic rate of the hosts, and time of infection and aggregation of the nematodes, to gain a better idea of the relationships between $A$. hylambatis and its amphibian hosts.

Finally, this type of study makes it clear that research on new species of nematodes, especially of cosmocercids should be based on as many specimens as possible. Description based on few worms may not reveal the variations in morphological and metrics characters described above.

\section{ACKNOWLEDGMENTS}

We are grateful to Dr. Regina Draghi for specimens collected in $R$. arenarum from La Plata, Buenos Aires province, and to Dr. Eduardo Sanabria and Dr. Lorena Quiroga for specimens collected in $R$. arenarum from Presidente Sarmiento, San Juan province. Financial support was provided by Consejo Nacional de Investigaciones Científicas y Técnicas (CONICET) of Argentina, through grant PIP 0111 to M. I. Hamann, and by Fondo para la Investigación Científica y Tecnológica (FONCYT) of Argentina, through grant PICT 2016-1991 to V. I. Gómez.

\section{AUTHOR CONTRIBUTIONS}

CEG and MIH collected the data and conceived the ideas. VIG and CEG designed methodology and analyzed the data. CEG made the figures and led the writing of the manuscript. All authors contributed critically to the drafts and gave final approval for publication.

\section{REFERENCES}

ADDINSOFT. 2017. Xlstat for excel, version 2017.2. Addinsoft, New York.

BAKER MR. 1980. Revision of Old World species of the genus Aplectana Raillet \& Henry, 1916 (Nematoda, Cosmocercidae). Bull Mus Natl Hist Nat Paris Ser 4 Sect A 2: 955-998.

BAKER MR AND VAUCHER C. 1986. Parasitic helminths from Paraguay XII: Aplectana Raillet y Henry, 1916 (Nematoda: Cosmocercoidea) from frogs. Rev Suisse Zool 93: 607-616.

BALLESTEROS-MÁRQUEZ A. 1945. Revisión de la familia Cosmocercidae Travassos, 1925. Rev Iber Parasitol Tomo Extraordinario: 150-180.

BARČÁK D, OROS M, HANZELOVÁ V AND SCHOLZ T. 2014. Phenotypic plasticity in Caryophyllaeus brachycollis Janiszewska, 1953 (Cestoda: Caryophyllidea): does fish host play a role? Syst Parasitol 88: 153-166.

BAYLIS HA. 1927. On two new species of Oxysomatium (Nematoda), with some remarks on the genus. Ann Mag Nat Hist Ser 19: 279-286.

BENESH DP AND KALBE M. 2016. Experimental parasite community ecology: intraspecific variation in a large 
tapeworm affects community assembly. J Anim Ecology 85: 1004-1013.

BLANKESPOOR HD. 1974. Host-induced Variation in Plagiorchis noblei Park, 1936 (Plagiorchiidae: Trematoda). Am MidI Nat 92: 415-433.

BRAZENOR AK, SAUNDERS RJ, MILLER TL AND HUTSON KS. 2018. Morphological variation in the cosmopolitan fish parasite Neobenedenia girellae (Capsalidae: Monogenea). Int J Parasitol 48: 125-134.

BURSEY CR, GOLDBERG SR AND TELDFORD JR SR. 2006. New species of Aplectana (Nematoda: Cosmocercidae) and Mesocoelium monas (Digenea: Brachycoeliidae) in Lepidophyma flavimaculatum (Squamata: Xantusiidae) from Costa Rica. Caribb J Sci 42: 164-170.

CAMPIÃO KM, DA SILVA ICO, DALAZEN GT, PAIVA F AND TAVARES LER. 2016. Helminth Parasites of 11 Anuran Species from the Pantanal Wetland, Brazil. Comp Parasitol 83: 92-100.

CAMPIÃO KM, MORAIS DH, TAVARES DIAS O, AGUIAR A, TOLEDO GM, TAVARES LER AND DA SILVA R. 2014. Checklist of Helminth parasites of Amphibians from South America. Zootaxa 3843: 1-93.

CATALANO S, LEJEUNE M, VAN PARIDON B, PAGAN CA, WASMUTH JD, TIZZANI P, DUIGNAN PJ AND NADLER SA. 2015. Morphological variability and molecular identification of Uncinaria spp. (Nematoda: Ancylostomatidae) from grizzly and black bears: new species or phenotypic plasticity? J Parasitol 101: 182-192.

CHITWOOD MB. 1957. Intraspecific Variation in Parasitic Nematodes. Syst Zool 6: 19-23.

DOWNES BJ. 1990. Host induced morphology in mites: implications for host parasite coevolution. Syst Zool 39: 162-168.

DRAGHI R, LUNASCHI LI AND DRAGO FB. 2015. First report of helminth parasitizing Trachycephalus typhonius (Anura: Hylidae) from northeastern Argentina. Rev Mex Biodiv 86: 255-261.

DYER WG. 1990. Augmented description of Aplectana travassosi (Nematoda: Cosmocercidae) from leptodactylid frogs of Ecuador. J Parasitol 76: 639-640.

FAGERHOLM HP. 1989. Intra-specific variability of the morphology in a single population of the seal parasite Contracaecum osculatum (Rudolphi) (Nematoda, Ascaridoidea), with a redescription of the species. Zool Scripta 18: 33-41.

FROST DR. 2018. Amphibian Species of the World: An Online Reference. Version 6.0 (April 04, 2018). Electronic Database available at http://research.amnh.org/ herpetology/amphibia/index.html. American Museum of Natural History, New York, USA.

GHARAMAH AA, RAHMAN WA AND SITI AZIZAH MN. 2014. Morphological variation between isolates of the nematode Haemonchus contortus from sheep and goat populations in Malaysia and Yemen. J Helminthol 88: 8288.

GÓMES DC AND DA MOTTA C. 1967. Sôbre um nôvo gênero e uma nova espécie de Oxyascarididae (Travassos, 1920) Freitas, 1958 (Nematoda, Subuluroidea). Mem Inst Oswaldo Cruz 65: 29-31.

GONZÁLEZ CE AND HAMANN MI. 2015. Checklist of nematode parasites of amphibians from Argentina. Zootaxa 3980: 451-476.

GRABDA-KAZUBSKA B AND COMBES C. 1981. Morphological variability of Haplometra cylindracea (Zeder, 1800) (Trematoda, Plagiorchiidae) in populational and geographic aspects. Acta Parasitol Polonica 28: 39-65.

HALEY JA. 1962. Role of host relationships in the systematics of helminth parasites. J Parasitol 8: 671-678.

HAMANN MI AND GONZÁLEZ CE. 2015. Helminth parasites in the toad Rhinella major (Bufonidae) from Chaco region, Argentina. Acta Herpetol 10: 93-101.

HAMMER O, HARPER DAT AND RYAN PD. 2001. PAST: Paleontological Statistics Software Package for Education and Data Analysis. Palaeontol Electron 4: 9.

HANZELOVÁ V, OROS M, BARČAK D, MIKLISOVÁ D, KIRIN D AND SCHOLZ T. 2015. Morphological polymorphism in tapeworms: redescription of Caryophyllaeus laticeps (Pallas, 1781) (Cestoda: Caryophyllidea) and characterisation of its morphotypes from different fish hosts. Syst Parasitol 90: 177-190.

HILDEBRAND J, ADAMCZYK M, LASKOWSKI Z AND ZALEŚNY G. 2015. Host-dependent morphology of Isthmiophora melis (Schrank, 1788) Luhe, 1909 (Digenea, Echinostomatinae) - morphological variation vs. molecular stability. Parasit Vectors 8: 481.

HUSSAIN KJ, KRISHNAN SM, JOHNY S AND WHITMAN DW. 2013. Phenotypic Plasticity in a Gregarine Parasite (Apicomplexa: Eugregarinordia) Infecting Grasshoppers. Comp Parasitol 80: 233-239.

KELEHEAR C, SPRATT DM, DUBEY S, BROWN GP AND SHINE R. 2011. Using combined morphological, allometric and molecular approaches to identify species of the genus Raillietiella (Pentastomida). PLoS ONE 6: e24936.

KELEHEAR C, SPRATT DM, O'MEALLY D AND SHINE R. 2014. Pentastomids of wild snakes in the Australian tropics. Int J Parasitol Parasites Wildl 3: 20-31.

KENNEDY MJ. 1980a. Host-induced variations in Haematoloechus buttensis (Trematoda: Haematoloechidae). Can J Zool 58: 427-442.

KENNEDY MJ. 1980b. Geographical variation in some representatives of Haematoloechus Looss, 1899 (Trematoda: Haematoloechidae) from Canada and the United States. Can J Zool 58:1151-1167. 
KOHN A, FERNANDES BMM AND BAPTISTA-FARIAS FD. 1997. Redescription of Prosthenhystera obesa (Diesing, 1850) (Callodistomidae, Digenea) with New Host Records and Data on Morphological Variability. Mem Inst Oswaldo Cruz 92: 171-179.

KORALLO-VINARSKAYA NP, VINARSKI MV, KHOKHLOVA IS, SHENBROT GI AND KRASNOV BR. 2015. Interspecific variation of body size in a gamasid mite Laelaps clethrionomydis: environment, geography and host dependence. Parasitol Research 114: 3767-3774.

LENT H AND FREITAS JFT. 1948. Una coleçao de nematodeos, parasitos de vertebrados, do Museu de Historia Natural de Montevideo. Mem Inst Oswaldo Cruz 46: $1-71$

LEÓN- RÈGAGNON V, BROOKS DR AND PEREZ-PONCE DE LEÓN G. 1999. Differentiation of Mexican Species of Haematoloechus Looss, 1899 (Digenea: Plagiorchiformes): Molecular and Morphological Evidence. J Parasitol 85: 935-946.

LEÓN-RÈGAGNON V, GUILLEN-HERNÁNDEZ S AND ARIZMENDI-ESPINOSA MA. 2005. Intraspecific variation of Haematoloechus floedae Harwood, 1932 (Digenea: Plagiorchiidae), from Rana spp. in North and Central America. J Parasitol 91: 915-921.

MASI PALLARES R AND MACIEL S. 1974. Helminthes en batracios del Paraguay (1ra. Parte), con descripción de una nueva especie Aplectana pudenda (Oxyuridae: Cosmocercinae). Rev Paraguaya Microbiol 9: 55-60.

MATEJUSOVÁ I, KOUBKOVÁ B, GELNAR M AND CUNNINGHAM CO. 2002. Paradiplozoon homoion Bychowsky \& Nagibina, 1959 versus P. gracile Reichenbach-Klinke, 1961 (Monogenea): two species or phenotypic plasticity? Syst Parasitol 53: 39-47.

MCGARIGAL K, CUSHMAN S AND STAVORD SG. 2000. Multivariate statistics for wildlife and ecology research. New York: Springer, 248 p.

MICHEL JF, LANCASTER MB AND HONG C. 1972. Host induced effects on the vulval flap of Ostertagia ostertagi. Int J Parasitol 2: 305-317.

MIDEO N AND REECE SE. 2012. Plasticity in parasite phenotypes: evolutionary and ecological implications for disease. Future Microbiol 7: 17-24.

MLADINEO I, ŠEGVIĆ-BUBIĆ T, STANIĆ R AND DESDEVISES Y. 2013. Morphological Plasticity and Phylogeny in a Monogenean Parasite Transferring between Wild and Reared Fish Populations. PLoS ONE 8: e62011.

MORELLO J, MATTEUCI SD, RODRIGUEZAF AND SILVA ME. 2012. Ecorregiones y Complejos Ecosistémicos Argentinos. 1st. ed., Buenos Aires: Orientación Gráfica Editora, 719 p.

PERKINS SL, MARTINSEN ES AND FALK BG. 2011. Do molecules matter more than morphology? Promises and pitfalls in parasites. Parasitology 138: 1664-1674.
PIÑEIRO GOMEZ MD, GONZÁLEZ CE AND SANABRIA EA. 2017. A new species of Aplectana (Nematoda: Cosmocercidae) parasite of Pleurodema nebulosum (Anura: Leptodactylidae) from the Monte desert, Argentina, with a key to Neotropical species of the genus Aplectana. Zootaxa 4247: 121-130.

POULIN R. 2003. Information about transmission opportunities triggers a life-history switch in a parasite. Evolution 57: 2899-2903.

PROKOPIC J AND KRIVANEK K. 1974. Trematodes of the genus Haematoloechus Looss, and their variability. Helminthologia 15: 779-802.

REECE SE, RAMIRO RS AND NUSSEY DH. 2009. Plastic parasites: sophisticated strategies for survival and reproduction? Evol Appl 2: 11-23.

RHODEN HR AND BOLEK MG. 2011. Distribution and reproductive strategies of Gyrinicola batrachiensis (Oxyuroidea: Pharyngodonidae) in larvae of eight species of amphibians from Nebraska. J Parasitol 97: 629-635.

SUAREZ VH AND CABARET J. 1992. Interbreeding in the subfamily Ostertaginae (Nematoda: Trichostrongylidae) of rumiants. J Parasitol 78: 402-405.

TINSLEY RC AND JACKSON JA. 1998. Speciation of Protopolystoma Bychowsky, 1957 (Monogenea: Polystomatidae) in hosts of the genus Xenopus (Anura: Pipidae). Syst Parasitol 40: 93-141.

TRAVASSOS L. 1931. Pesquisas helmintológicas realizadas em Hamburgo. IX Ensaio monográfico da família Cosmocercidae Trav., 1925 (Nematoda). Mem Inst Oswaldo Cruz 25: 237-298.

VAIRA M. 2004. Population morphological variation of the monogenean Polystoma andinum, parasitic in Melanophryniscus rubriventris (Anura, Bufonidae). Acta Parasitol 49: 281-291.

VHORA MS AND BOLEK MG. 2013. New host and distribution records for Aplectana hamatospicula (Ascaridida: Cosmocercidae) in Gastrophryne olivacea (Anura: Microhylidae) from the Great Plains U.S.A. J Parasitol 99: 417-420.

VINEY M AND DIAZ A. 2012. Phenotypic plasticity in nematodes. Evolutionary and ecological significance. Worm 1: 98-106.

VIZOSO DB AND EBERT DJ. 2005. Phenotypic plasticity of host-parasite interactions in response to the route of infection. Evol Biol 18: 911-921.

WHARTON GW. 1957. Intraspecific variation in the parasitic acarina. Syst Zool 6: 24-28.

YUEN PH. 1965. Some studies on the taxonomy and development of some rhabdiasoid and cosmocercoid nematodes from Malayan amphibians. Zool Anz 174: 275 298. 